\title{
"Outside the Institute there is a Desert": The Tenuous Trajectories of Medical Research in Interwar Australia
}

\author{
PETER GRAEME HOBBINS*
}

Throughout the fin de siècle, medical research institutes increasingly hallmarked "modernity" across industrialized nations and their colonies. ${ }^{1}$ While the reification of these "veritable laboratory Xanadus" as insular centres for pure science has recently been questioned, ${ }^{2}$ the absence of such facilities in Australia prior to the First World War had enduring ramifications for public, political and professional perceptions of scientific medicine. Indeed, the handful of establishments that arose between 1910 and 1939 merit attention precisely because they so patently embodied local projections of "medical research". Underpinned by a pragmatic progressivism, yet constrained by fealty to empire, the enterprises emerging during this period were predominantly British in flavour and modern in their ideals. In both form and function, however, the early Australian research institutes were never simple facsimiles of international models. Instead, each was shaped by local accommodations in defining its mission and value within a culture often indifferent-and not infrequently hostile - to basic research. Indeed, each of these ventures constituted an experiment, or rather a contingent series of experiments, to triangulate itself within a favourable medical, social and political space.

Yet the development of the early Antipodean research institutes resists a teleological reading. Most subsisted with fewer than ten to fifteen staff, and many stagnated or failed outright. In the absence of a stable funding base or a groundswell of investigators

(C) Peter Graeme Hobbins 2010

* Peter Graeme Hobbins, M Medical Hum, Medical Humanities Unit, University of Sydney, Sydney; and Australian Venom Research Unit, Department of Pharmacology, University of Melbourne, Melbourne, Australia; peter_hobbins@bigpond.com

I am grateful for the enthusiastic mentorship of Alison Bashford and Ken Winkel, plus the recollections and comments provided by James Guest, Margaret Holmes, Keith Jones, Clyde Scaife and Frank, William and Michael Kellaway. The anonymous reviewers' detailed suggestions also contributed significantly to the final manuscript.

\footnotetext{
${ }^{1}$ For instance, Paul Weindling, 'Scientific elites and laboratory organisation in fin de siecle Paris and Berlin: the Pasteur Institute and Robert Koch's Institute for Infectious Diseases compared', in Andrew Cunningham and Perry Williams (eds), The laboratory revolution in medicine, Cambridge University Press, 1992, pp. 170-88; Joan Austoker,
}

A history of the Imperial Cancer Research Fund, 1902-1986, Oxford University Press, 1988, pp. 28-30; Harry M Marks, The progress of experiment: science and therapeutic reform in the United States, 1900-1990, Cambridge University Press, 2000, pp. 48-50; Annick Guénel, 'The creation of the first overseas Pasteur Institute, or the beginning of Albert Calmette's Pastorian career', Med. Hist., 1999, 43: 1-25; David Arnold, 'Colonial medicine in transition: medical research in India, 1910-47', S. Asia Res., 1994, 14: 10-35, pp. 13-16; J Norman Parmer, 'Health and health services in British Malaya in the 1920s', Mod. Asian Stud., 1989, 23: 49-71, p. 56.

${ }^{2}$ Daniel J Kevles and Gerald L Geison, 'The experimental life sciences in the twentieth century', Osiris, 1995, 10: 97-121, p. 104. See also Steve Sturdy, 'Knowing cases: biomedicine in Edinburgh, 1887-1920', Soc. Stud. Sci., 2007, 37: 659-89, pp. 660-1; Andrew J Hull, 'Teamwork, clinical research, and the development of scientific medicines in interwar Britain: the "Glasgow school" revisited', Bull. Hist. Med., 2007, 81: 569-93, pp. 570-2. 


\section{Peter Graeme Hobbins}

determined to make a career of research, these enterprises could have reverted to the status of little more than diagnostic laboratories. In responding to the challenge laid down by Steve Sturdy and Roger Cooter a decade ago, ${ }^{3}$ this article explicates the circumstances and strategies by which laboratory-based science negotiated a place in Australian medicine. My focus lies primarily with the most successful establishment, Melbourne's Walter and Eliza Hall Institute of Research in Pathology and Medicine, directed between 1923 and 1944 by Charles Kellaway (1889-1952). I argue that Kellaway's willingness to experiment with the form, function and funding of the Hall Institute not only ensured its own survival, but created exemplars and infrastructure that fostered medical research as a locally viable career.

\section{Isolated Endeavours}

By the outbreak of the First World War, "research" embodied several overlapping practices in Australian medicine. Reflecting its British origins, there was a strong clinical tradition of publishing noteworthy cases or cohorts, which gradually incorporated scientific investigations as an aid to stabilizing disease definitions. ${ }^{4}$ The confluence of laboratory techniques with epidemiological surveys likewise served the ambitions of public health physicians, whether curbing the spread of diphtheria along remote railway lines or elucidating the transmission of plague in Australia's most populous city. ${ }^{5}$ The nation's medical schools - at the universities of Adelaide, Melbourne and Sydney-were predominantly centres for vocational instruction. ${ }^{6}$ Occasionally, however, they accommodated inspired embryological, anatomical or physiological researchers such as Charles Martin or Grafton Elliot Smith, whose comparative methodologies flowed seamlessly into zoology or anthropology and advanced Australian biology beyond its nineteenth-century cataloguing mission. ${ }^{7}$ Isolated in a different sense were clinician researchers who explored multifarious phenomena from filariasis to bites by Australia's venomous fauna. ${ }^{8}$

What united these disparate conceptions of research, however, was that they were rarely projected as a corporate enterprise. Indeed, most Australian research projects undertaken prior to 1914 were piecemeal, part-time and lacking the approbation of the

\footnotetext{
${ }^{3}$ Steve Sturdy and Roger Cooter, 'Science, scientific management, and the transformation of medicine in Britain c.1870-1950', Hist. Sci., 1998, 36: 421-66, p. 449.

${ }^{4}$ John C Burnham, 'Biomedical communication and the reaction to the Queensland childhood lead poisoning cases elsewhere in the world', Med. Hist., 1999, 32: 155-72, pp. 156-60; K S Inglis, Hospital and community: a history of the Royal Melbourne Hospital, Melbourne University Press, 1958, pp. 124-5.

${ }^{5}$ Margaret Spencer, John Howard Lidgett Cumpston, C.M.G., M.D., D.P.H., Tenterfield, NSW, Margaret Spencer, 1987, p. 99; P H Curson, Times of crisis: epidemics in Sydney 1788-1900, Sydney University Press, 1985, pp. 138-58.

${ }^{6}$ Ann Mozley Moyal, 'Medical research in Australia: a historical perspective', Search, 1981, 12:
}

302-9, p. 302; K F Russell, The Melbourne Medical School 1862-1962, Melbourne University Press, 1977, pp. 123-6.

${ }^{7}$ Harriette Chick, 'Charles James Martin. 1866-1955', Biog. Mem. Fellows R. Soc., 1956, 2: 172-208, pp. 175-7; Barbara J Hawgood, 'Sir Charles James Martin MB FRS: Australian serpents and Indian plague, one-hundred years ago', Toxicon, 1997, 35: 999-1010, pp. 1001-7; Patricia Morison, $J T$ Wilson and the Fraternity of Duckmaloi, Amsterdam, Rodopi, 1997, pp. 98-100.

${ }^{8}$ John Pearn and Kenneth D Winkel, 'Toxinology in Australia's colonial era: a chronology and perspective of human envenomation in nineteenth century Australia', Toxicon, 2006, 48: 726-37, pp. 732-4; R Doherty, 'Australia's contribution to tropical health: past and present', Med.J. Aust., 1993, 158: 552-7, pp. 552-3. 


\section{The Tenuous Trajectories of Medical Research in Interwar Australia}

centres in which they were conducted. Even the most productive collaborations, such as the "Fraternity of Duckmaloi" forged by Martin, James Wilson and James Hill at Sydney University in the 1890s, were short-lived and rarely survived the departure of the principal investigators. ${ }^{9}$ The same fate essentially befell the prototypical institutes that flowered briefly before the First World War, including the Pasteur Institute of Australia (1888-98) and the New South Wales Bureau of Microbiology (1908-13). ${ }^{10}$ Further proposals for formalized centres of investigation-such as an Institute of Preventive Medicine in Victoria (1891)—remained stillborn. ${ }^{11}$ This absence of dedicated facilities did not, of course, preclude continuance of local clinical, laboratory or epidemiological studies. However, the dearth of centres offering scientific and pedagogical continuity shaped the perceptions and practice of Australian medical science well into the new century. This attitude is exemplified by the Commonwealth government's first support for such research, which comprised an annual grant to subsidize tropical medicine studies in Britain. ${ }^{12}$

Historians largely cite the First World War as the predominant reason for the growth in Australian medical research. This argument comprises three main historiographic threads. The first is an emphasis on population health prompted by appalling wartime casualty lists. ${ }^{13}$ The second is the recognition that Australia had to mobilize local resources to fend off threats to national health. ${ }^{14}$ The third thread relates to militarymedical exchange, particularly the exposure of Australian doctors to modern British methods of hygiene, bacteriology, surgery and research whilst serving overseas. ${ }^{15}$ These factors converged with a growing popular perception of health as a fundamental right, ${ }^{16}$

\footnotetext{
${ }^{9}$ Morison, op. cit., note 7 above, pp. 88-116.

${ }^{10}$ Stephen Dando-Collins, Pasteur's gambit: Louis Pasteur, the Australasian rabbit plague and a ten million dollar prize, North Sydney, Vintage Books, 2008; Jan Todd, 'The Pasteur Institute of Australiasuccess and failure', in Jean Chaussivert and Maurice Blackman (eds), Louis Pasteur and the Pasteur Institute in Australia, Kensington, NSW, University of New South Wales, 1988, pp. 25-37; Peter J Tyler, “ “A pathologist of distinction": Frank Tidswell, 1867-1941', Individuals \& institutions in the history of medicine: proceedings of the 6th biennial conference of The Australian Society of the History of Medicine, Sydney, The Organising Committee of the 6th Biennial Conference of the Australian Society of the History of Medicine, 1999, pp. 1-4.

${ }^{11}$ This venture was mooted by Melbourne University's professor of medicine, Harry Brookes Allen. See Vivianne de Vahl Davis, 'Sir Harry Allen and the foundation of the Walter and Eliza Hall Institute of Medical Research', Hist. Rec. Aust. Sci., 1980, 5: 31-8, p. 32; Inglis, op. cit., note 4 above, pp. 125-6.

${ }^{12}$ The amount was $£ 200$ per annum from 1905 to 1910. See Lorraine Harloe, 'Anton Breinl and the Australian Institute of Tropical Medicine', in Roy MacLeod and Donald Denoon (eds), Health and
}

healing in tropical Australia and Papua New Guinea, Townsville, James Cook University, 1991, pp. 35-46, on p. 39.

${ }^{13} \mathrm{~J}$ H L Cumpston, The health of the people: a study in federalism, Canberra, Roebuck, 1978, p. 30 .

${ }^{14}$ A H Brogan, Committed to saving lives: a history of the Commonwealth Serum Laboratories, South Yarra, Hyland House, 1990, pp. 1-11; Claire Hooker and Alison Bashford, 'Diphtheria and Australian public health: bacteriology and its complex applications, c.1890-1930', Med. Hist., 2002, 46: 41-64, pp. 55-7.

${ }^{15}$ Roy MacLeod, 'From imperial to national science', in Roy MacLeod (ed.), The commonwealth of science: ANZAAS and the scientific enterprise in Australasia, 1888-1988, Melbourne and Oxford, Oxford University Press, 1988 , pp. 40-72, on p. 60; Earle Page, Truant surgeon: the inside story of forty years of Australian political life, Sydney, Angus \& Robertson, 1963, pp. 42-4.

${ }^{16}$ Grant Rodwell, 'Lessons from the First World War: Drs Harvey Sutton and J S Purdy: Sydney's Health Week: 1921-1950', Individuals \& institutions in the history of medicine, op. cit., note 10 above, pp. 1-4, on p. 2; Cumpston, op. cit., note 13 above, p. 16. 


\section{Peter Graeme Hobbins}

at a time when the colonial image of the generalist practitioner was being surpassed by conceptions of medicine as a collective scientific endeavour. ${ }^{17}$

Beyond the Armistice, however, local research continued to be stymied by the absence of supportive structures. Australia between the wars has been characterized as a nation turning in on itself: proud of its military record, scarred by its wartime sacrifice and exhibiting deep, parochial pessimism towards intellectual endeavours of almost any flavour. ${ }^{18}$ Yet public mistrust of science after the technological horrors of the war competed with a growing - if grudging - progressivist acceptance of "expertise". Research was accommodated not to generate fundamental knowledge, but pragmatically to solve pressing technical problems in pursuit of national efficiencies. ${ }^{19}$ While such initiatives assisted Australian self-sufficiency, Roy MacLeod in particular has argued that ongoing local deference to British expertise perpetuated an enervated "Commonwealth science". 20

Indeed, Australians graduating after 1918 rarely entertained a scientific career in their homeland. Frederick Courtice cites the haphazard nature of previous research projects and ongoing Dominion fealty to Britain to explain why local research programmes were starved of talented individuals. ${ }^{21} \mathrm{He}$ identifies several aspects of this phenomenon, including the constraints of Australian scientific isolation, the appeal of London and the ease with which Australians_-as British citizens_could win Imperial scholarships to undertake research in the UK. Rod Home extends this argument, positing the Royal Society as "an empire-wide system of scientific patronage and reward that helped keep colonial science firmly bound to that of the metropolis". ${ }^{22}$ Hugh Hamersley further contends that the absence of a local tradition of full-time research presented two substantial barriers for the Australian scientific centres that developed after $1910 .{ }^{23}$ A lack of opportunity and tutelage denied promising investigators the means to further their ambitions, while those who persevered found no local models or mentors. Thus researchers responsible for running the enterprises that faltered into existence during the interwar period had precious few precedents or pathways to follow.

\footnotetext{
${ }^{17} \mathrm{~T}$ S Pensabene, The rise of the medical practitioner in Victoria, Canberra, Australian National University, 1980, pp. 159, 177; James Gillespie, 'Medical markets and Australian medical politics, 1920-45', Labour Hist., 1988, 54: 30-46.

${ }^{18}$ MacLeod, op. cit., note 15 above, pp. 59-60, 64-5.

${ }^{19}$ For instance, Kate Murphy, 'The "most dependable element of any country's manhood": masculinity and rurality in the Great War and its aftermath', Hist. Aust., 2009, 5: 72.1-20, pp. 72.9-10; C B Schevdin, Shaping science and industry: a history of Australia's Council for Scientific and Industrial Research, 1926-49, Sydney, Allen \& Unwin, 1987, p. 38.

${ }^{20}$ Roy MacLeod, 'Science, progressivism, and "practical idealism": reflections on efficient imperialism and federal science in Australia, 1895-1915', in Roy MacLeod and Richard Jarrell (eds), Dominions apart: reflections on the culture of science and technology in Canada and Australia
}

1850-1945, Ontario, Canadian Science and Technology Historical Association, 1994, pp. 7-25, on p. 24.

${ }^{21} \mathrm{~F}$ C Courtice, 'Research in the medical sciences: the road to national independence', in R W Home (ed.), Australian science in the making, Cambridge University Press, 1988, pp. 277-307, on pp. 285-7.

${ }^{22} \mathrm{R}$ W Home, "A world-wide scientific network and patronage system: Australian and other "colonial" fellows of the Royal Society of London', in R W Home and Sally Gregory Kohstedt (eds), International science and national scientific identity Australia between Britain and America, Dordrecht, Kluwer Academic Publishers, 1991, pp. 151-80, on p. 151.

${ }^{23}$ Hugh Hamersley, 'Cancer, physics and society: interactions between the wars', in Home (ed.), op. cit., note 21 above, pp. 197-219, on pp. 198-200. 


\section{The Tenuous Trajectories of Medical Research in Interwar Australia}

Local industry did not fill the void. Unlike the expanding commercial research ventures in Europe and North America, ${ }^{24}$ the Australian pharmaceutical industry remained essentially a manufactory and importer of overseas innovations until at least the Second World War. ${ }^{25}$ Commonwealth support for commercial innovation grew during the interwar years via the Council for Scientific and Industrial Research, but its remit never extended to medical or pharmaceutical science. ${ }^{26}$ However, Council studies in animal nutrition and disease did occasionally intersect with medical science, as did work at the Queensland Stock Institute in Brisbane and the Waite Agricultural Research Institute in Adelaide. ${ }^{27}$

An enduring medical research culture was also rare within Australian universities. Although medical faculties had grudgingly increased preclinical science teaching within their curricula, it was not until the 1930s that medical schools and teaching hospitals meaningfully engaged with Flexnerian reforms to medical education. ${ }^{28}$ In contrast to the philanthropic cornucopia trailing in Abraham Flexner's wake across the northern hemisphere, Australian faculties struggled against escalating teaching loads and stifling pecuniary limitations. For instance, in 1925 Melbourne University had only $£ 2400$ invested for medical research; by 1932 its annual disbursement remained a mere $£ 824$, less than a single professor's salary. ${ }^{29}$ When Richard Berry-the University's professor of anatomy-was asked in 1925 how research could be made appealing to students, he remarked:

I had the same question put to me twenty years ago ... The prevailing idea then was, as it is now apparently, that we expect the young graduate in medicine ... to do research work for which he has no training whatever, at remuneration varying from $£ 50$ to $£ 150$ per annum. He has no experience, and knows very little about it. The position to-day is practically as it was then. ${ }^{30}$

Furthermore, the limited number of faculties and the historical absence of a vigorous research culture meant that-unlike Britain $^{31}$ - there was no cadre of ambitious

\footnotetext{
${ }^{24}$ For example, E M Tansey, 'The Wellcome Physiological Research Laboratories 1894-1904: the Home Office, pharmaceutical firms, and animal experiments', Med. Hist., 1989, 33: 1-41, pp. 35-41; Nicolas Rasmussen, 'The moral economy of the drug company-medical scientist collaboration in interwar America', Soc. Stud. Sci., 2004, 34: 161-85, pp. 163-8; Alison Li, J.B. Collip and the development of medical research in Canada: extracts and enterprise, Montreal, McGill-Queen's University Press, 2003, pp. 41-2, 57-8.

${ }^{25}$ See, for instance, R Grenville Smith and Alexander Barrie, Aspro-how a family business grew up, Melbourne, Nicholas International, 1976; John F T Grimwade, A short history of Drug Houses of Australia Ltd to 1968, Richmond, John F T Grimwade, 1974.

${ }^{26}$ MacLeod, op. cit., note 15 above, pp. 64-5; Schevdin, op. cit., note 19 above, pp. 36-8, 49.

${ }^{27}$ Dando-Collins, op. cit., note 10 above, pp. 304-5; Claire Hooker, Irresistible forces: Australian women in science, Carlton, Melbourne University Press, 2004, pp. 127-8.

${ }^{28}$ Russell, op. cit., note 6 above, pp. 98-117; Morison, op. cit., note 7 above, pp. 126-9; Peter
}

McPhee, 'Pansy': a life of Roy Douglas Wright, Carlton, Melbourne University Press, 1999, pp. 21-3.

${ }^{29}$ George A Syme, Royal Commission on Health. Minutes of evidence, Melbourne, Commonwealth of Australia, 1925, p. 227; McPhee, op. cit., note 28 above, pp. 38-9.

${ }^{30}$ Syme, op. cit., note 29 above, p. 233.

A comfortable professional existence in mid-1920s Australia might entail a salary of $£ 500$ per annum; university lecturers earned $£ 600$ and professors $£ 900$ (Robert Murray, The confident years: Australia in the twenties, London, Allen Lane, 1978, pp. 142, 172).

${ }^{31} \mathrm{See}$, for example, Steve Sturdy, 'From the trenches to the hospitals at home: physiologists, clinicians and oxygen therapy, 1914-30', in John V Pickstone (ed.), Medical innovations in historical perspective, Basingstoke, Macmillan, 1992, pp. 104-23; Steve Sturdy, 'War as experiment: physiology, innovation and administration in Britain 1914-1918: the case of chemical warfare', in Roger Cooter, Mark Harrison and Steve Sturdy (eds), War, medicine and modernity, Thrupp, Stroud, Sutton Publishing, 1998, pp. 65-84; David Cantor, 'The MRC's support for experimental radiology during the inter-war years', in Joan Austoker and Linda 


\section{Peter Graeme Hobbins}

academics clamouring to expand their clinical stature or to promulgate research-driven pedagogy. ${ }^{32}$ By 1935, the need for a more conducive culture was seen as pressing: "Senior men lament the present necessary frustration of their aspirations both as personal contributors to knowledge and as directors of the efforts of the younger men they have inspired." 33 Yet while medical academics played key roles in establishing several of the early research institutes in Australia, their support bespoke a view of research as an activity best undertaken beyond the campus. ${ }^{34}$ Even in 1948, Melbourne University's professor of bacteriology, Sydney Rubbo, could observe that:

The tendency has been here in Australia to establish units in medical research institutes outside the universities because research is a full time job ... and hence a university whose time is devoted largely to teaching is not such a fruitful source in which to spend money. ${ }^{35}$

Admittedly, Cancer Research Committees were formed at both Melbourne and Sydney Universities in 1915 and 1922, respectively. ${ }^{36}$ While the former pursued a low-key trajectory directed by physicist Thomas Laby, the Sydney venture traced a spectacular parabola under its indifferent professor of physiology, Henry Chapman. The Sydney Cancer Research Committee coordinated a substantial research programme that was disseminated across the campus and several local hospitals-what might now be classed a "virtual institute". However, despite riding high on a bounty of donations and promising experimental results-certainly it was the most well-resourced venture by 1929 - the programme was moribund by 1934 and wound up in 1938. Although the associated tale of adultery, misappropriated funds and scientific myopia is diverting in itself, the Sydney experience moreover offers a salutary counterpoint to narratives of biomedical ascendance. Indeed, late into the 1930s the unsupportive university climate continued to drive luminaries such as Hugh Ward, Frederic Wood Jones and Roy "Pansy" Wright to better-funded schools abroad. Students eager to carve out a local career in medical science thus found few models at their alma maters. Many turned, instead, to the handful of formal research institutes that had evolved after 1910.

\section{The Institutional Topography}

The earliest of the formal medical research institutes to be configured as such was the Australian Institute of Tropical Medicine (AITM), opened on 1 January $1910 .{ }^{37}$ In the

Bryder (eds), Historical perspectives on the role of the MRC: essays in the history of the Medical Research Council of the United Kingdom and its predecessor, the Medical Research Committee, 1913-1953, Oxford University Press, 1989, pp. 181-204, on pp. 200-3.

${ }^{32}$ Although naturally, individual exceptions existed; see Hamersley, op. cit., note 23 above, p. 200; James Guest, John Hunter's discipleFrederic Wood Jones, Vicary Lecture, 1989, London, Royal College of Surgeons of England, 1989, pp. 4-7.

${ }^{33}$ University of Melbourne Archives (hereafter UMA), Melbourne, ASAP 3/3/85, Folder 8/7, 'Memorandum on University Medical School development and the market site', 9 Apr. 1936, p. 4.

\footnotetext{
${ }^{34}$ For instance, de Vahl Davis, op. cit., note 11 above; Moyal, op. cit., note 6 above, p. 302.

35 Australian National University, 'Medical Research in Australia: report of proceedings of the conference convened by the Interim Council at the request of Sir Howard Florey, F.R.S.', Canberra, 3-4 April 1948, p. 9.

${ }^{36}$ Hamersley, op. cit., note 23 above.

${ }^{37}$ The AITM is by far the most studied-and theorized —of the early Australian research institutes; see, for instance, J H L Cumpston, 'The Australian Institute of Tropical Medicine', Med. J. Aust., 1923, 1: 398-400; R A Douglas, 'Dr Anton Breinl and the Australian Institute of Tropical Medicine, part 1', Med. J. Aust., 1977, 1: 713-16; ibid., part 2, Med.J.
} 


\section{The Tenuous Trajectories of Medical Research in Interwar Australia}

post-Federation era, this annexe to the Townsville Hospital represented an important step for Australian investment in health, being supported in part by the Queensland government and-increasingly after 1914-Commonwealth funding. ${ }^{38}$ The research policy established by the first director-the Viennese protozoologist Anton Breinl-initially paralleled similar ventures in India and the Federated Malay States, ${ }^{39}$ namely facilitating imperial commercial progress by optimizing the health of both white and "native" labour. However, in quantifying physiological aspects of "the great experiment of populating tropical Australia by a white working community", the AITM's research increasingly drew inspiration from American investigations in the Philippines. ${ }^{40}$ From 1921 the institute's course skewed again when it fell under the aegis of the newly formed Commonwealth Department of Health and its autocratic Director-General, (John) Howard Cumpston. Complementing the profusion of Commonwealth Health Laboratories that fanned out across the Australian landscape in the 1920s, the AITM fulfilled an increasingly instrumental role as a diagnostic laboratory for disease classification and epidemiology, and as a mouthpiece for public health promotion. ${ }^{41}$ Indeed, Cumpston and a new, non-experimentalist overseer, Raphael Cilento, envisaged the institute as a nexus for projecting Australian medical expertise outwards to the imperial Pacific territories. ${ }^{42}$ However, this vision waned in the latter half of the 1920s-along with the AITM's scientific output and its Commonwealth funding — and the facility closed, transmogrifying in 1930 into the School of Public Health and Tropical Medicine at Sydney University.

Nevertheless, federal interest in health extended beyond tropical medicine. Opened in 1918, the Commonwealth Serum Laboratories (CSL) was not primarily a research venture; rather, it was a manufacturing plant inaugurated to reverse Australia's dependence on imported sera and vaccines. ${ }^{43}$ In his previous guise as national Director of Quarantine, Cumpston had been instrumental in realizing this federally owned enterprise, although the titular director at its inception was William Penfold, a British-trained bacteriologist. While CSL's structure included allowance for research and development work, it was only after Penfold was replaced in 1927 by the Australian bacteriologist Frederick Morgan that the Laboratories were permitted to undertake epidemiological, microbiological, immunological and therapeutic investigations. A dedicated research department was formally established in 1934, at which point Morgan projected CSL as a

Aust., 1977, 1: 748-51; ibid., part 3, Med. J. Aust., 1977, 1: 784-90; Harloe, op. cit., note 12 above.

${ }^{38} \mathrm{M}$ Roe, 'The establishment of the Australian Department of Health: its background and significance', in Cumpston, op. cit., note 13 above, pp. v-xxiii, on p. xxii; Moyal, op. cit., note 6 above, pp. 302-3.

${ }^{39}$ Arnold, op. cit., note 1 above, pp. 13-16; Parmer, op. cit., note 1 above, p. 56.

${ }^{40}$ Warwick Anderson, 'Geography, race and nation: remapping "tropical” Australia, 1890-1930', Hist. Rec. Aust. Sci., 1997, 11: 457-68, p. 463.

${ }^{41}$ Andrew Parker, 'A "complete protective machinery"-classification and intervention through the Australian Institute of Tropical Medicine, 1911-1928', Health Hist., 1999, 1: 181-200, pp. 189-94; F G Morgan, 'The Commonwealth
Serum Laboratories and their work', Coll. Proc. Soc. Chem. Ind. Victoria, 1935, 35: 1015-31, pp. 1019-20; Malcolm Whyte, A global scientist: Douglas H. K.

Lee, Gundaroo, Brolga Press, 1995, pp. 27-31.

${ }^{42}$ Fedora Gould Fisher, Raphael Cilento: $a$ biography, St Lucia, University of Queensland Press, 1994, pp. 40, 46-8; Warwick Anderson, The cultivation of whiteness: science, health and racial destiny in Australia (2nd ed.), Carlton, Melbourne University Press, 2005, pp. 162-4; Alexander Cameron-Smith, 'Australian imperialism and International Health in the Pacific Islands', Aust. Hist. Stud., 2010, 41 (in press).

${ }^{43}$ Brogan, op. cit., note 14 above, p. 1; W J Penfold, 'The Commonwealth Serum Laboratories', Med. J. Aust., 1923, 1: 396-400. 


\section{Peter Graeme Hobbins}

semi-autonomous "institute": "It would be a mistake to regard the Commonwealth Serum Laboratories as purely an institution for the commercial manufacture of biological products, though it may be of interest to know that the Institute is entirely selfsupporting." 44 A Commonwealth Radium Laboratory was also instigated in Melbourne in 1928 to disburse $£ 100,000$ worth of radium purchased from federal funds for cancer treatment, but this remained largely a coordination, standardization and occupational health concern rather than a research venture. ${ }^{45}$

The same was essentially true of the microbiology and pathology laboratories funded by individual states such as South Australia, New South Wales and Queensland. Although opportunistic studies were initiated at these facilities-such as Edward "Ted" Derrick's mid-1930s investigation of $Q$ fever-such research was infrequent and remained entirely subservient to routine diagnostic work. ${ }^{46}$ Ambitious researchers, however, agitated for the evolution of the Adelaide laboratory into the Institute of Medical and Veterinary Science (IMVS) in 1938, while its northern counterpart begat the Queensland Institute of Medical Research in $1946 .{ }^{47}$ The federal government also supported the Commonwealth Institute of Anatomy, which opened in Canberra in 1931. This enormous accumulation of indigenous fauna was first housed in Melbourne as the Australian Institute of Anatomical Research (1919), before being donated to the Commonwealth government in 1924 under the initial title of the National Museum of Australian Zoology. ${ }^{48}$ While small-scale investigations were undertaken into comparative physiology, human nutrition and childhood development, the Institute of Anatomy never approached its goal of becoming "comparable with the Hunterian Museum of the Royal College of Surgeons ... the centre of research into the advance of medical science in Australia". 49

The remaining establishments that arose prior to the Second World War more closely resembled international models of dedicated research facilities such as the Lister or Pasteur Institutes. These included Melbourne's Hall Institute (inaugurated in 1915 but in abeyance until 1919) and the Thomas Baker, Alice Baker and Eleanor Shaw Medical Research Institute (1927). ${ }^{50}$ Sydney boasted the Institute of Pathological Research of

\footnotetext{
${ }^{44}$ Morgan, op. cit., note 41 above, pp. 1016, $1020-3$.

${ }^{45}$ Hamersley, op. cit., note 23 above, pp. 206-11, $214-15$

${ }^{46}$ Robin A Cooke, 'Q fever. Was Edward Derrick's contribution undervalued?', Med.J. Aust., 2008, 189: 660-2; Macfarlane Burnet, Changing patterns: an atypical autobiography, Melbourne, William Heinemann, 1968, pp. 100-4.

${ }^{47} \mathrm{E}$ Weston Hurst, 'The Institute of Medical and Veterinary Science', Aust. J. Sci., 1941, 4: 10-11; E H Derrick, 'The birth of the Queensland Institute of Medical Research', Med. J. Aust., 1972, 2: 952-9.

${ }^{48}$ A J Proust, 'Sir Colin MacKenzie and the Institute of Anatomy', Med.J. Aust., 1994, 161: 60-2; Stuart Braga, ANZAC doctor: the life of Sir Neville Howse, Australia's first V.C., Sydney, Hale \& Iremonger, 2000, pp. 310-11.
}

\footnotetext{
${ }^{49}$ Anon., 'Anatomy. Institute at Canberra. Centre of research in Australia', The Sydney Morning Herald (Sydney), 27 Aug.1930: 17; Guy Hansen, Collecting for a nation, National Museum of Australia, 2005 at http://www.nma.gov.au/exhibitions/past_exhibitions/ captivating_and_curious/collecting_for_a_nation/ (accessed 25 Aug. 2009).

${ }^{50}$ Macfarlane Burnet, Walter and Eliza Hall Institute 1915-1965, Melbourne, Melbourne University Press, 1971; Vivianne de Vahl Davis, 'A history of the Walter and Eliza Hall Institute of Medical Research, 1915-1978: an examination of the personalities, politics, finances, social relations and scientific organization of the Hall Institute', PhD thesis, University of New South Wales, 1979; de Vahl Davis, op. cit., note 11 above; Thomas E Lowe, The Thomas Baker, Alice Baker and Eleanor Shaw Medical Research Institute, Melbourne, The Trustees of the Baker Medical Research Institute, 1977.
} 


\section{The Tenuous Trajectories of Medical Research in Interwar Australia}

New South Wales (1920, renamed the Kolling Institute of Medical Research in 1931) and the Kanematsu Memorial Institute of Pathology (1933). ${ }^{51}$ Paralleling the emergence of diagnostic bacteriological laboratories earlier in the century, ${ }^{52}$ all of these institutes were situated adjacent to metropolitan teaching hospitals and were frequently referred to- - even by their proponents - as appendages subsisting off their hosts. Their primary role was likewise couched clinically as the provision of routine laboratory investigations, with original work only to be undertaken when time permitted. Perhaps where these institutes most differed was in their relationships with universities. Some, like the Baker, Kolling and Kanematsu Institutes, had few administrative or instructional ties, while the Hall Institute and the IMVS promulgated closer associations with local medical faculties, albeit subservient to hospital-institute bonds. None, however, shared a stable financial base, remaining dependent on tenuous amalgams of private or public philanthropy, admixed with hospital service fees and intermittent state government subsidies. ${ }^{53}$

\section{Transplanted Templates and Team Work}

If, as I contend, these early Australian facilities constituted distinct experiments with the form, function and rhetoric of local medical research, what was the medium in which they grew or withered? Where did their models arise, and how were they projected and promulgated? Moreover, what factors allowed certain configurations to prosper and be carried forward as prototypes for the less straitened circumstances after 1945 ?

It is unsurprising that directors of these nascent institutes modelled their facilities upon international exemplars; until the 1940s, Australian doctors desirous of specializing or pursuing a research career had few options but to travel "home" to Britain. ${ }^{54}$ Many sojourned at the Lister Institute under the tutelage of Charles Martin, whose encouragement of Antipodean science- "the Martin spirit"-endured from his 1890s tenure in Australia until his death in 1955. ${ }^{55}$ Frank Macfarlane Burnet, for example, observed from London: "I have a terrific respect for $\mathrm{C} \mathrm{J}$ Martin and if he definitely advises me to any course of action it will take a great deal of moral courage to go counter to it." ${ }^{, 56}$ Several key AITM staff were also recruited from the Lister, while Breinl had directed Liverpool's Runcorn Laboratory before entering his iron-roofed shack in Townsville. ${ }^{57}$ In 1916, William

\footnotetext{
${ }^{51}$ David S Nelson, 'The Kolling Institute of Medical Research', Med. J. Aust., 1985, 143: 97-101; F C Courtice, 'The Kanematsu Memorial Institute of Pathology: the Inglis era, 1933-60', Hist. Rec. Aust. Sci., 1985, 6: 115-36; Paul C Vincent and Belinda L Vincent, 'The Kanematsu Institute 1933-1982', in Harold Attwood, Richard Gillespie and Milton James Lewis (eds), New perspectives on the history of medicine: first national conference of the Australian Society of the History of Medicine, Melbourne, University of Melbourne and the Australian Society of the History of Medicine, 1990, pp. 261-70.

${ }^{52}$ Hooker and Bashford, op. cit., note 14 above, p. 51.

${ }^{53}$ For instance, see Syme, op. cit., note 29 above, pp. 226-7, 230-1.
}

\footnotetext{
${ }^{54}$ See Anon., 'Post-graduate work in London', The Speculum, June 1925: 22-5; Ian J Wood, Discovery and healing in peace and war: an autobiography, Toorak, Ian J Wood, 1984, pp. 20-7; Burnet, op. cit., note 46 above, pp. 37-41.

${ }^{55}$ Two biographies of Martin are currently in preparation; for his influence on Australia, see Morison, op. cit., note 7 above, pp. 406-10; Richard Stawell, 'Professor Sir Charles J Martin,

F.R.S. An appreciation', The Speculum, July 1931:

5-6; Hawgood, op. cit., note 7 above.

${ }^{56}$ UMA, ASAP 3/3/85, Folder 2/10, Macfarlane Burnet to Linda Druce, 1 Sept. 1927, p.1.

${ }^{57}$ Douglas, op. cit., note 37 above (part 1), p. 749; Harloe, op. cit., note 12 above, p. 42.
} 


\section{Peter Graeme Hobbins}

Penfold - another Lister alumnus - completed an exhaustive tour of major English, French and American laboratories which fed first into the form of CSL and, a decade later, the Baker Institute. $^{58}$

As occurred in interwar Canada, the rising stature of US research and a panoply of Rockefeller Foundation and Carnegie Corporation fellowships gradually encouraged ambitious Australians to consider American forays. ${ }^{59}$ Complementing Archibald Hill's Academic Assistance Council in Britain, these philanthropies further accelerated transnational intellectual exchange by relocating expatriate German scientists to Australia from 1933 onwards. Max "Rudi" Lemberg joined the Kolling Institute and Bernard Katz the Kanematsu, while Wilhelm Feldberg worked at the Hall Institute from 1936 to $1938 .^{60}$ A talented pharmacologist central to Henry Dale's Nobel Prize-winning work on chemical neurotransmission, Feldberg keenly felt the Australian disdain for research, lamenting that "outside the institute there is a desert scientifically, and that is often a little depressing after London". 61

Given such unpromising soil for their germinal enterprises, how did Australian institute directors transplant and nurture the seeds they had brought with them from afar? In analysing the establishment and ultimate dissolution of the Sydney Cancer Research Committee between 1922 and 1938, Hamersley elucidates some of the complexity that governed success or failure of Australian medical research enterprises during the interwar era. ${ }^{62}$ Among the contributors to success were a vision and commitment to research as a professional undertaking, considered financial management, administrative discipline, scientific leadership and diversity of research programmes. Louella McCarthy's study of Sydney's Rachel Forster Hospital over the same period identifies factors of equal importance, including the ideologies and connections of the institution's proponents, the creation of a profitable niche for the venture, and a willingness to nuance institutional rhetoric better to meet political needs in an era of increasing government responsibility for health. ${ }^{63}$ In particular, McCarthy ascribes considerable value to the personal and professional qualities of key staff members. Working within the framework erected by these two scholars, I maintain that the Hall Institute under Charles Kellaway represented the most successful Australian research enterprise of the interwar years. In charting Kellaway's models and methods, I hope concurrently to demonstrate why the paths travelled by his contemporaries were less salutary, both for their institutes and for the deeper soil within which medical research became locally self-sustaining.

\footnotetext{
${ }^{58}$ Brogan, op. cit., note 14 above, p. 5.

${ }^{59}$ For example, Whyte, op. cit., note 41 above, pp. 37-8; Desmond Zwar, The Dame: the life and times of Dame Jean Macnamara, medical pioneer, Melbourne, Macmillan, 1984, pp. 21-31. For the Canadian equivalent, see especially Alison I-Syin Li, 'J. B. Collip and the making of medical research in Canada', PhD thesis, University of Toronto, 1992, p. 286.

${ }^{60}$ R D Wright, 'What Australian physiology owes to Adolph Hitler', Proc. Aust. Physiol. Pharmacol. Soc., 1983, 14: 22-7; see also Paul Weindling, 'An overloaded ark? The Rockefeller Foundation and refugee medical scientists, 1933-45', Stud. Hist. Phil.
}

Biol. Biomed. Sci., 2000, 31: 477-89; Walter and Eliza Hall Institute of Medical Research archives (hereafter WEHA), Melbourne, WEHA00043, 'Correspondence-Feldberg 1934-1939'.

${ }^{61}$ Royal Society Library and Archives (hereafter RSL), London, HD/24/1/75/74, Wilhelm Feldberg to Henry Dale, 15 Nov. 1937, p. 8.

${ }^{62}$ Hamersley, op. cit., note 23 above, pp. 200, 211.

${ }^{63}$ Louella McCarthy, 'Idealists or pragmatists? Progressives and separatists among Australian medical women, 1900-1940', Soc. Hist. Med., 2003, 16: $263-82$, pp. $267-8,272-5$. 


\section{The Tenuous Trajectories of Medical Research in Interwar Australia}

Kellaway entered Melbourne University in 1907, determined to become a medical missionary in India. ${ }^{64}$ Despite ructions in his training caused by the faculty's new emphasis on pre-clinical sciences, he became one of its "most brilliant graduates", subsequently earning both MD and MS degrees. ${ }^{65}$ Like almost a third of Australian doctors, he served during the First World War, an experience that demolished his religious faith but reinforced the value of imperial exchange in medical ideas, techniques and organization. ${ }^{66}$ The conflict also provided Kellaway with two enormously serendipitous connections. In Egypt with the Australian Army Medical Corps, he worked as a bacteriologist under Charles Martin, who described Kellaway in 1916 as "a delightfully keen and very able young man [and] a good Pathologist". ${ }^{67}$ Their field research on dysentery formed the basis for Kellaway's first scientific contributions to the medical literature. ${ }^{68}$ Attached to the Australian Flying Corps two years later in London, he was encouraged to undertake investigations under Henry Dale at what became the National Institute of Medical Research (NIMR), then housed at the Lister Institute. Dale, already an eminent pharmacologist and physiologist, was impressed with Kellaway's "keenness, aptitude and conscientious industry" during studies on anoxaemia at altitude. ${ }^{69}$

In addition to its military applications, Kellaway's research intimately connected him with the bloc of influential physiologists whose wartime work was fostered by the British Medical Research Committee (from 1920 the Medical Research Council, MRC). ${ }^{70}$ As argued particularly by Steve Sturdy, the conflict and its aftermath had provided these basic scientists with opportunities not merely to expand their clinical role, but to promulgate a culture of experiment across military and political establishments. ${ }^{71}$ Unlike his Australian peers whose post-Armistice banners unfurled in public health, social medicine or outright eugenics, Kellaway's ambitions never ran to reshaping society in the mould of scientific medicine. ${ }^{72}$ Nevertheless, he did not fail to appreciate the growing

\footnotetext{
${ }^{64}$ There is currently no full biography of Kellaway. The only autobiographical account of any length is RSL, 'Charles H. Kellaway personal information file', c.1944; for detailed obituaries, see H H Dale, 'Charles Halliley Kellaway, 1889-1952', Obit. Not. Fellows R. Soc., 1953, 8: 502-21;

F M Burnet, 'Obituary: Charles Halliley Kellaway', Med. J. Aust., 1953, 1: 203-7.

${ }^{65}$ Russell, op. cit., note 6 above, pp. 98-103, 109-10; Anon., 'Dr. C. H. Kellaway', The Age (Melbourne), 14 Dec. 1952.

${ }^{66}$ A J Proust, A companion of the history of medicine in Australia 1788-1939, Forrest, A J Proust, 2003, p. 237; National Archives of Australia (hereafter NAA), Canberra, Series B2455, 'Charles

Halliley Kellaway, personal service record 1915-20’; Frank Kellaway to Peter Hobbins (in possession of the author), Feb. 2007, p. 1.

${ }^{67}$ Basser Library, Australian Academy of Science, Canberra, File 11/1/1, Charles Martin to Harriette Chick, 5 May (addendum to letter originally dated 26 April) 1916.

${ }^{68}$ C J Martin, C H Kellaway and F E Williams, 'Epitome of the results of the examination of the
}

stools of 422 cases admitted to No. 3 Australian General Hospital, Cairo, for dysentery and diarrhoea; March to August 1916', J. R. Army Med. Corps, 1918, 30: 101-2.

${ }^{69}$ Dale, op. cit., note 64 above, pp. 505-6; C H Kellaway, Reports of the Air Medical Investigation Committee. 8. The effects of diminished tension of oxygen, with especial reference to the activity of the renal glands, Special report series (Great Britain. Medical Research Committee) 37, London, His Majesty's Stationery Office, 1919.

${ }^{70}$ See National Health Insurance, Fifth annual report of the Medical Research Committee 1918-1919, London, His Majesty's Stationery Office, 1919, pp. 22-3; T Michael Gibson and Michael H Harrison, 'Aviation medicine in the United Kingdom: early years, 1911-1918', Aviat. Space Environ. Med., 2005, 76: 599-600.

${ }^{71}$ Sturdy, 'From the trenches to the hospitals at home' and 'War as experiment' (both op. cit., note 31 above).

${ }^{72}$ Anderson, op. cit., note 42 above, pp. 166-8; Fisher, op. cit., note 42 above, pp. 29-32. 


\section{Peter Graeme Hobbins}

confluence between scientific and bureaucratic modes of management, nor the opportunities it presented for British medical scientists. Indeed, Burnet later remarked of Kellaway: "Clearly there would be a London flavour to whatever he created in Australia and he may well have had the Lister Institute in mind as a model.",73

Despite Martin's early influence, however, Kellaway's time at the Lister was superseded by subsequent templates. Upon repatriation to Australia, he taught briefly in Adelaide before winning the inaugural Foulerton Studentship offered by the Royal Society of London. This stipend enabled him to return to Britain, working from 1920 to 1923 in the laboratories of some of the most influential medical researchers of the time. ${ }^{74}$ In his first year he resumed work with Dale at the new NIMR in Hampstead, followed by a brief sojourn with Charles Sherrington at Oxford University before settling at the University College Hospital (UCH) in London under Thomas Elliott.

While Sherrington's department represented the established model of fundamental physiological research isolated from clinical practice, ${ }^{75}$ post-war London was a ferment of new structures and practices. Contrasting with the rearguard action fought by casebased clinicians, ${ }^{76}$ the NIMR epitomized the ascendance of "modern", problem-based research that had developed during the war. ${ }^{77}$ While the institute operated ostensibly as four departments-biochemistry and pharmacology, applied physiology, bacteriology, and statistics-Dale's collaborative approach overrode these nominal boundaries. This credo manifested formally in the open layout of his laboratories and the constitution of cross-disciplinary teams, and informally via discussions across shared benches and at tea-breaks. ${ }^{78}$ The specific conception of "team work" promulgated by Dale-problemdriven, interdisciplinary collaboration between laboratory scientists-was the model endorsed by Walter Fletcher at the MRC in his quest to winkle clinicians out of basic research. ${ }^{79}$ Its effect on Kellaway's institutional imaginings can be detected in statements he made after returning to Australia:

... in these days when a problem has to be tackled it often requires team work of a very high order. It may require an expert bio-chemist, another expert in morbid anatomy, another in experimental

\footnotetext{
${ }^{73}$ Burnet, op. cit., note 50 above, p. 22.

${ }^{74}$ Both Martin and Dale were members of the Foulerton Research Fund Managing Committee; see RSL, CMB/64/4, 'Minutes, meeting of the Foulerton Research Fund Managing Committee', 22 Nov. 1922; Dale, op. cit., note 64 above, pp. 506-9.

${ }^{75}$ E M Tansey, 'Working with C. S. Sherrington', Notes Rec. R. Soc., 2008, 62: 123-30.

${ }^{76}$ See, for instance, Christopher Lawrence, 'A tale of two sciences: bedside and bench in twentiethcentury Britain', Med. Hist., 1999, 43: 421-49; Christopher Lawrence, 'Still incommunicable: clinical holists and medical knowledge in interwar Britain', in Christopher Lawrence and George Weisz (eds), Greater than the parts: holism in biomedicine, 1920-1950, New York and Oxford, Oxford University Press, 1998; Sturdy and Cooter, op. cit., note 3 above, pp. 436-46.

${ }^{77}$ Robert E Kohler, 'Walter Fletcher, F. G. Hopkins, and the Dunn Institute of Biochemistry:
}

a case study in the patronage of science', Isis, 1978, 69: 331-55, pp. 336-40.

${ }^{78}$ Elliot S Valenstein, The war of the soups and the sparks: the discovery of neurotransmitters and the dispute over how nerves communicate, New York, Columbia University Press, 2005, p. 50; E M Tansey, 'An F4-vescent episode: Sir Henry Dale's laboratory 1919-1942', Br. J. Pharmacol., 1995, 115: 1339-45.

${ }^{79}$ Joan Austoker, 'Walter Morley Fletcher and the origins of a basic biomedical research policy', in Austoker and Bryder (eds), op. cit., note 31 above, 1989, pp. 23-34, on pp. 26-30; Cantor, op. cit., note 31 above, pp. 200-3. This rendering of Fletcher's position is disputed by David Smith in 'The use of "team work" in the practical management of research in the inter-war period: John Boyd Orr at the Rowett Research Institute', Minerva, 1999, 37: 259-80, pp. 277-8. 


\section{The Tenuous Trajectories of Medical Research in Interwar Australia}

medicine, and a fourth in bacteriology; they may all be needed for an adequate solution of a problem ... Team work is becoming essential, and if we want to foster research work in this country it is very important to develop the idea of doing it in proximity to people who are grappling the problems side by side, and supplementing the deficiencies in each other. ${ }^{80}$

It is clear from this rhetoric that despite his military service and hospital training under aloof consultants, Kellaway favoured an egalitarian, "side by side" conception of team work-the "group work" that Canadian researchers had so spectacularly employed in the 1922 discovery of insulin. ${ }^{81}$ This ethos was borne out at the Hall Institute wherelike both Dale and Martin-Kellaway's contribution to others' projects was to advise and enthuse, rather than to dictate or discipline. ${ }^{82} \mathrm{He}$ thus eschewed the alternative "hierarchical teamwork" approach that was accelerating internationally as research programmes grew in size and complexity, and as the power base of ambitious laboratory chiefs expanded commensurately. ${ }^{83}$

Yet Kellaway's practice veered away from another key aspect of Dale's "team work", namely the hermetic separation of laboratory and clinic. He never lost his physician's desire to treat individual patients, nor could he deny his institute's role in addressing the pressing needs of hospital cases and community epidemics such as poliomyelitis. ${ }^{84}$ This constitutional unwillingness to abandon clinical practice was not uncommoneither locally or internationally_but it was certainly fostered by the Hall Institute's conceptualization as a subsidiary of the Melbourne Hospital, as well as the prevailing pragmatism of Australian science. ${ }^{85}$ As a result, Kellaway promoted a porous, problem-driven approach to team work at the Hall Institute, encouraging both loose and formalized alliances between laboratory workers and clinicians.

This inclusive stance also betrayed Kellaway's years within London's University College Hospital complex, which in the early 1920s piloted the integration of teaching, research and clinical practice into a cohesive medical "unit". ${ }^{86}$ The UCH unitencompassing interlinked hospital, university and laboratory facilities-was generously funded by the Rockefeller Foundation as a model for reforming British medical training along Flexnerian lines. The application of physiological techniques to UCH patients was illustrated by Kellaway's collaboration with Thomas Elliott to standardize insulin dosing, privileging quantifiable biochemical measurements over clinical observation. ${ }^{87}$ While remaining wary of veering too far from "problems with direct practical application to

\footnotetext{
${ }^{80}$ Syme, op. cit., note 29 above, p. 231.

${ }^{81}$ Smith, op. cit., note 79 above, p. 278 ; Li, op. cit., note 59 above, pp. 44-54.

${ }^{82}$ Tansey, op. cit., note 78 above, p. 1341; Harriette Chick, Margaret Hume and Marjorie Macfarlane, War on disease: a history of the Lister Institute, London, Andre Deutsch, 1971, p. 70; Wood, op. cit., note 54 above, pp. 14-16.

${ }^{83}$ The term is Andrew Hull's (op. cit., note 2 above, pp. 579-80); see also Li, op. cit., note 24 above, pp. 91-4; Smith, op. cit., note 79 above, pp. 266-75.

${ }^{84} \mathrm{C} \mathrm{H}$ Kellaway, The sixth annual report of the Walter and Eliza Hall Institute of Research in
}

Pathology and Medicine, Melbourne, The Walter and Eliza Hall Institute, 1926, pp. 8-9.

${ }^{85}$ See Marks, op. cit., note 1 above, p. 46; Martin Edwards, Control and the therapeutic trial: rhetoric and experimentation in Britain, 1918-48, Amsterdam, Rodopi, 2007, pp. 16-17.

${ }^{86}$ Donald Fisher, 'The Rockefeller Foundation and the development of scientific medicine in Great Britain', Minerva, 1978, 16: 20-41, pp. 28-30.

${ }^{87}$ Desirée Cox-Maksimov, 'The making of the clinical trial in Britain, 1910-1945: expertise, the state and the public', PhD thesis, University of Cambridge, 1997, pp. 175-7. 


\section{Peter Graeme Hobbins}

formal medicine", ${ }^{88}$ Kellaway also apprehended the ascendance of academic medicine in the new London schema, having served as acting Professor of Anatomy (1915) and then acting Professor of Physiology (1919) at the University of Adelaide. Indeed, upon returning to Australia in 1923, Kellaway persevered for twenty years in seeking to position the Hall Institute in closer relation both to the Melbourne Hospital and Melbourne University - in essence to replicate the triumvirate of facilities that made up the UCH unit.

\section{"A More or Less Complex Unit"}

On arriving at the Hall Institute in 1923, Kellaway set about remaking it along more modern London lines. Although the institute ostensibly comprised departments of bacteriology, biochemistry, histology, serology and experimental pathology, these appear to have been a farrago of routine clinical services rather than dedicated research streams. ${ }^{89}$ An early step was to coalesce these erratic methodologies into specific departments reflecting those at the NIMR, namely physiology, bacteriology and biochemistry. ${ }^{90}$ Although, like Dale, Kellaway continued to construct project teams across the institute, the formalized departments provided his researchers with a degree of autonomy and the disciplinary identity necessary to develop and disseminate their expertise. Yet unlike other scientific empire builders of the period, he neither favoured his own department nor stifled the emergence of new divisions. ${ }^{91}$ Indeed, Kellaway not only fostered Burnet's emerging virology laboratory; after 1935 he gave it precedence over his own work in the institute's annual reports. By the end of that decade, the Hall Institute also boasted a pioneering blood transfusion service and moved towards clinical research in immunization.

In accommodating such diverse interests among established and potential investigators, this multiplicity of experimental disciplines enhanced the Hall Institute's appeal as a local centre for aspiring medical scientists. In contrast, most other Australian institutes focused on only one or two research streams: the AITM on tropical physiology, the Kolling Institute on biochemistry, the Kanematsu on neurophysiology, and the Baker on both bacteriology and biochemistry. ${ }^{92}$ Rather than specializing to dominate specific fields, such narrow directions were a bald recognition of financial stringency. However, these strictures left the new research ventures on shaky ground. In his study of the Sydney Cancer Research Committee, for instance, Hamersley notes that failure of the programme's central research thrust was a major factor in its dissolution; ${ }^{93}$ Warwick Anderson likewise observes that completion of the AITM's physiological studies left the facility rudderless after $1920 .^{94}$

\footnotetext{
${ }^{88}$ University of Adelaide Library, Adelaide, MSS 0020, 'Series 2-letters received 1911-54', Charles H Kellaway to T G B Osborn, 11 May 1921, pp. 3-4.

${ }^{89}$ See S W Patterson, The Walter and Eliza Hall Institute of Research in Pathology and Medicine, Melbourne Hospital. Director's report, 1920, Melbourne, The Walter and Eliza Hall Institute, 1921, p. 3.

${ }^{90}$ De Vahl Davis, op. cit., note 50 above, pp. 42-3.
}

\footnotetext{
${ }^{91}$ See Smith, op. cit., note 79 above, pp. 263-6; Kohler, op. cit., note 77 above, pp. 332, 351.

${ }_{92}$ Anderson, op. cit., note 42 above, pp. 109-12; Lowe, op. cit., note 50 above, p. 18; Courtice, op. cit., note 21 above, pp. 297-8; E V Keogh, 'Fifty years of medical research in Australia', Med. J. Aust., 1951, 1: 24-8, p. 26; Nelson, op. cit., note 51 above, p. 97.

${ }_{93}$ Hamersley, op. cit., note 23 above, p. 215.

${ }^{94}$ Anderson, op. cit., note 42 above, pp. 145, $162-4$.
} 


\section{The Tenuous Trajectories of Medical Research in Interwar Australia}

Stability was thus a further benefit of Kellaway's experiment with diversifying the Hall Institute's research. While Burnet later suggested that this dissipated its strengths, Kellaway's wider mission was to nurture a broad base of trained medical researchers who could in turn develop their own programmes or institutions. ${ }^{95}$ This vision was not his alone; it was echoed by Cumpston at the inaugural meeting of the National Health and Medical Research Council (NH\&MRC) in $1937 .{ }^{96}$ However, by that stage Kellaway had been providing practical support to budding researchers for nearly fifteen years. In fact, the palpable success of the Hall Institute led other local institute boards to consult with Kellaway in creating their own structures. Both the Baker and the postwar Queensland Institute of Medical Research actively modelled their operations on aspects of the Hall Institute, ${ }^{97}$ while Kellaway was specifically commissioned to draft criteria for the director of the Kanematsu Institute, urging the appointment of John "Jack" Eccles in that role. 98

Well aware of the absence of local research opportunities and mentors, Kellaway was also assiduous in providing multiple working arrangements to tempt and nurture aspiring investigators. Even before his arrival, the institute had encouraged students and voluntary workers into full- or part-time research, ${ }^{99}$ but Kellaway extended an offer to "co-operate with Honorary Physicians and Surgeons in carrying out special investigations of problems, and to help in elucidating obscure cases"; indeed, the facility and its staff were "available for investigation of medical problems arising in all parts of the State". ${ }^{100}$ In addition to permanent employees, working relationships supported by the Hall Institute included visiting positions and training roles: even registrars willing to commit just two hours per week were encouraged. ${ }^{101}$ In promoting this porous conception of team work, Kellaway fostered a plexus of relationships between his laboratory and clinical medicine, claiming that "the whole institute forms a more or less complex unit [with the Melbourne Hospital]". 102

Although far from the only contemporary example-as Hull and Sturdy have demonstrated in the UK, for instance-this hybrid structure served important goals in interwar Australia. ${ }^{103}$ Kellaway repeatedly encouraged fellow doctors to systematize their practices, urging that there was "not one of us who may not make some contribution to knowledge" via clinical, diagnostic or basic sciences. ${ }^{104}$ The range of investigations undertaken at the Hall Institute similarly configured "scientific medicine" as a continuum of practices spanning isolated physiological preparations through to hospital

\footnotetext{
${ }^{95}$ C H Kellaway, 'The Sir Richard Stawell oration', Med. J. Aust., 1938, 1: 365-74, p. 370.

${ }^{96} \mathrm{~J}$ H L Cumpston, 'Appendix I. Inaugural address', Sixty years of the National Health and Medical Research Council 1936-1996, Canberra, Australian Government Printing Service, 1996 (facsimile of 1937 document), pp. 83-98, on p. 88.

${ }^{97}$ Derrick, op. cit., note 47 above, pp. 953-5; Lowe, op. cit., note 50 above, p. 17.

${ }^{98}$ Courtice, op. cit., note 51 above, pp. 119-21.

${ }^{99} \mathrm{~S}$ W Patterson, 'Post-graduate research work', The Speculum, Nov. 1922: 199-201, p. 200.
}

\footnotetext{
${ }^{100} \mathrm{C}$ H Kellaway, 'The Walter and Eliza Hall Research Institute', The Speculum, Nov. 1924: 101-3, p. 102.

${ }^{101} \mathrm{C}$ H Kellaway, The Walter and Eliza Hall Institute of Research in Pathology and Medicine. Eleventh annual report 1929-30, Melbourne, The Walter and Eliza Hall Institute, 1930, p. 38.

${ }^{102}$ Syme, op. cit., note 29 above, p. 229.

${ }^{103}$ Hull, op. cit., note 2 above, pp. 571-7; Sturdy, op. cit., note 2 above.

${ }^{104}$ C H Kellaway, Papers of Michael Kellaway (hereafter PMK), London, 'Address to Royal Melbourne Hospital', 1940, p. 4.
} 


\section{Peter Graeme Hobbins}

autopsies. ${ }^{105}$ Moreover, this schema allowed the institute to operate on many levels: by 1941 it supported both Australia's first repository of frozen serum for blood transfusion and the publication of Burnet's pivotal monograph on immunological theory. ${ }^{106}$

The necessity to retain a pragmatic appeal to clinicians was highlighted by Sydney's hospital-bound institutes. At the Kolling, Max Lemberg echoed Feldberg's sense of scientific desolation, describing his research environment as a "wilderness" bereft of support from Australian colleagues. ${ }^{107}$ At the Kanematsu-where the later Nobel laureates Eccles and Katz undertook basic neurophysiological studies-local clinicians and the hospital board were so antagonistic that both soon resigned for overseas posts. ${ }^{108}$ Geographical remoteness could be just as damning; the Australian Institute of Anatomy would almost certainly have fared better if the Royal Australasian College of Surgeons had relocated from Melbourne to Canberra, as initially intended. ${ }^{109}$ More directly, as the federal health purview shifted from the tropical north to the populous south of the continent, the AITM's very location in northern Queensland broadcast its peripheral status. Although reasons for its demise were multifarious, the AITM's isolation from Australia's main centres of practice and research provided sufficient rhetorical basis to justify its closure. ${ }^{110}$

\section{Promulgating Peer Networks}

Safely ensconced in central Melbourne, Kellaway repeatedly projected his institute outwards to garner both clinical and political support from the medical fraternity. Whilst specialists pursued medical research to enhance the stature and autonomy of their disciplines in interwar Britain, ${ }^{111}$ the limited scale of local investigations urges caution in extending this argument to Australia. There is little doubt, however, that Kellaway's alliance with hospital consultants benefited the Hall Institute, particularly as specialists increasingly came to dominate Australian medical politics between the wars. ${ }^{112}$ An eminently "clubbable" man, he considered consultants and academics his milieu, and throughout the period he remained an honorary physician at the Melbourne Hospital.

Kellaway furthermore taught and examined numerous clinicians for fellowship in the English and Australian professional colleges, especially under the aegis of the Melbourne

${ }^{105}$ See, for example, Charles H Kellaway, PMK, 'Our debt to medical science', 24 Oct. 1943.

${ }^{106}$ Lucy M Bryce, An abiding gladness: the background of contemporary blood transfusion and its story during the years 1929-1959 in the Victorian Division of the Australian Red Cross Society, Melbourne, Georgian House, 1965, p. 90; F M Burnet, Mavis Freeman, A V Jackson and Dora Lush, The production of antibodies: a review and a theoretical discussion, Monographs from the Walter and Eliza Hall Institute of Research in Pathology and Medicine-Melbourne, Number One, Melbourne, Macmillan, 1941.

\footnotetext{
${ }^{107}$ Courtice, op. cit., note 21 above, p. 298; Wright, op. cit., note 60 above, pp. 25-6.

${ }^{108}$ Courtice, op. cit., note 51 above, pp. 122-3; Vincent and Vincent, op. cit., note 51 above, pp. 63-4.

${ }^{109}$ Braga, op. cit., note 48 above, p. 312.

${ }^{110}$ Moyal, op. cit., note 6 above, p. 303.

${ }^{111}$ Austoker, op. cit., note 79 above, p. 30;
} George Weisz, Divide and conquer: a comparative history of medical specialization, Oxford University Press, 2006, pp. 227-8.

${ }^{112}$ Gillespie, op. cit., note 17 above, pp. 37-8; Ann Daniel, Medicine and the state, Sydney, Allen \& Unwin Australia, 1990, p. 86. 


\section{The Tenuous Trajectories of Medical Research in Interwar Australia}

Permanent Committee for Post-Graduate Work. ${ }^{113}$ Indeed, he was the only institute director to become a foundation councillor of the Association of Physicians of Australasia in 1930. From 1938 he served in a similar capacity for the new Royal Australasian College of Physicians, prior to being elected vice-president in 1942-a significant achievement for a "non-clinician". ${ }^{114}$ Although the creation of local specialist colleges challenged the hegemony of the British Medical Association as the main political body for Australian doctors, local BMA branches nevertheless retained considerable power through the interwar era. ${ }^{115}$ A steadfast presenter at state and national BMA meetings, Kellaway both promoted the value of his institute and encouraged the Association to lobby for Commonwealth government funding of research. ${ }^{116}$

In addition to this clinical concatenation, Kellaway followed the lead of Martin and Dale in establishing his own networks of patronage for "first-rate fellows" wishing to undertake research. Indeed, his unselfish support for the careers of others-from senior scientists literally through to cleaners-epitomizes recollections of Kellaway. ${ }^{117}$ Undoubtedly the most profound of his sponsorships was Burnet, who joined the Hall Institute only months before Kellaway arrived. He arranged for Burnet to earn his $\mathrm{PhD}$ under Martin at the Lister Institute and-fuelled by Kellaway's good reports-Dale subsequently offered Burnet a Rockefeller Foundation fellowship to undertake virus research at the NIMR. ${ }^{118}$ Thus was the cycle perpetuated. Moreover, it was a pattern that Kellaway recapitulated throughout his career, extending to his directorship of the Wellcome Research Institution from 1944 to $1952 .{ }^{119}$

This process was not, however, destined to favour Kellaway's own research in basic physiology and pharmacology. The interwar years have been rendered a gilded age for experimental physiology: championed by Abraham Flexner, generously supported by the MRC in Britain, driving patentable therapeutic innovations in North America and garnering scientific kudos across Europe. ${ }^{120}$ In Australia, Kellaway's experimental programme on Australian snake venoms was critical in enabling him to provide scientific

\footnotetext{
${ }^{113}$ For example, Frank Kellaway op. cit., note 66 above, pp. 3, 7; Anon., 'The Melbourne Permanent Committee for Post-Graduate Work', Med. J. Aust., 1931, 1: 181; The Melbourne Permanent Committee for Post-Graduate Work, The kidney in health and disease, Sydney, Australasian Medical Publishing, 1924, pp. 5-65.

${ }^{114}$ Anon., 'Australia [from our correspondent in Sydney]', Br. Med. J., 1931, i: 1086; S W Williams, 'Kellaway, Charles Halliley', in G L McDonald (ed.), Roll of the Royal Australasian College of Physicians, Sydney, Royal Australasian College of Physicians, 1988, pp. 156-7, on p. 157.

${ }^{115}$ Pensabene, op. cit., note 17 above, p. 163; Gillespie op. cit., note 17 above, p. 32.

${ }^{116}$ For instance, Anon., 'Snake venoms', Med. J. Aust., 1929, 2: 536-7; Anon., 'Mussel poison', Med. J. Aust., 1935, 1: 261.

${ }^{117}$ For example, Wood, op. cit., note 54 above, pp. 14, 27-9; G R Cameron, 'Charles Halliley Kellaway', J. Pathol. Bacteriol., 1953, 66: ix; Clyde Scaife, 'Charles Kellaway (CHK), director of Walter \&
}

Eliza Hall Institute of Research in Pathology \& Medicine (WEHI): his impact on the life of Clyde Scaife (CAS) in the years 1940 to 1943' (in possession of the author), 4 Apr. 2007, p. 2.

${ }^{118}$ Christopher Sexton, Burnet: a life, 2nd ed., Melbourne and Oxford, Oxford University Press, 1999, pp. 50-61, 71-8; Neeraja Sankaran, 'Frank Macfarlane Burnet and the nature of the bacteriophage, 1924-1937', PhD thesis, Yale University, 2006, pp. 224-39.

${ }^{119}$ A Rupert Hall and B A Bembridge, Physic and philanthropy: a history of the Wellcome Trust, 1936-1986, Cambridge University Press, 1986, pp. 64-5.

${ }^{120}$ As recognized by the award of the 1936 Nobel Prize to Henry Dale and Otto Loewi for their research on chemical neurotransmission. See also Kevles and Geison, op. cit., note 2 above, pp. 104-5; Valenstein, op. cit., note 78 above, pp. 71-86; Sturdy, 'From the trenches to the hospitals at home', op. cit., note 31 above, pp. 117-23. 


\section{Peter Graeme Hobbins}

leadership at the Hall Institute. ${ }^{121}$ These studies immediately generated concrete clinical outcomes, including guidelines on management of envenomed patients and collaboration with CSL to manufacture the first local antivenene. ${ }^{122}$ Furthermore, Kellaway's corpus of work in this field-over sixty published papers-earned him accolades including the Fellowship of the Royal Society of London and the prestigious 1936 Charles E Dohme Memorial Lectureship at Johns Hopkins University. The associated kudos ensured Kellaway's status as a significant scientific actor, both in the domestic setting and in negotiation with international bodies such as the Rockefeller Foundation. ${ }^{123}$

Beyond the Hall Institute, however, Kellaway's "physiological experiment" faltered. While his international scientific credentials were acknowledged, his oeuvre of venom studies was perceived as interesting but peripheral to clinical medicine. ${ }^{124}$ Perhaps hoping to bolster physiology locally, Kellaway had invited Feldberg to sojourn at the Hall Institute and was instrumental in drawing Eccles to the Kanematsu. ${ }^{125}$ However, after two years Feldberg chose the more cosmopolitan environment of Cambridge, while Eccles' programme with Katz and Stephen Kuffler was stifled by academic isolation and marginalized as "remote from clinical usefulness". ${ }^{126}$ Tropical physiology had prospered briefly at the AITM before 1920 and developed again in Queensland from the late 1930s, but few centres pursued physiological investigations beyond anthropological fieldwork and wartime trials for adaptation of military personnel to tropical service. ${ }^{127}$ Coupled with the absence of pharmaceutical industry research, physiology thus never supplanted bacteriology as the epitome of medical science in interwar Australia. This patchy record furthermore confirmed that, unlike basic research programmes in the northern hemisphere, Australian medical science could not subsist on the premise that fundamental discoveries would-ultimately_inform better clinical practice.

More successful, however, were Kellaway's attempts to complete the "unit" triad by negotiating a closer relationship with the University of Melbourne. Throughout the era, he ensured that Hall Institute staff maintained clinical posts at the Melbourne Hospital and teaching positions at the university, both to promote the institute and to spot potential talent. However, most of the early Australian institutes shared few enduring programmes with local universities-certainly not in the new London mould-although eager students occasionally undertook short-term projects. ${ }^{128}$ While academic staff held positions on the Hall Institute board, the facility had always been more closely aligned with the hospital, sharing as they did both personnel and physical locations. As

\footnotetext{
${ }^{121}$ For a detailed review of Kellaway's scientific work, see Peter Hobbins, 'Serpentine science: Charles Kellaway and the fluctuating fortunes of venom research in interwar Australia', Hist. Rec. Aust. Sci., 2010, 21 (in press).

${ }^{122} \mathrm{C} \mathrm{H}$ Kellaway and F G Morgan, 'The treatment of snake bite in Australia', Med.J. Aust., 1931, 2: 482-5.

${ }^{123}$ This was a critical consideration for Foundation funding through the era; see Edgar Jones and Shahina Rahman, 'The Maudsley Hospital and the Rockefeller Foundation: the impact of philanthropy on research and training',
}

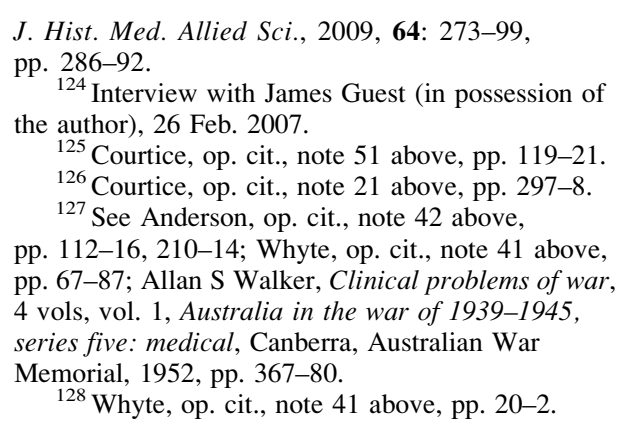




\section{The Tenuous Trajectories of Medical Research in Interwar Australia}

the need for the hospital to relocate became more pressing during the 1920s, a site became available adjacent to Melbourne University. Kellaway seized this opportunity not just to secure more modern premises, but physically to locate the Hall Institute where he felt it belonged conceptually: between a university and a major teaching hospital. More pragmatically, he hoped that this reconfiguration might allow the institute to dispense with its routine duties and focus on cooperative research with the university. ${ }^{129}$

The move also prompted Kellaway to propose that the director of the Hall Institute should become Australia's first professor of experimental medicine. This was not mere vainglory: Melbourne University acknowledged that the arrangement "would secure an outstanding investigator and organizer for the chair at relatively small cost". ${ }^{130}$ Mirroring Dale's supervision of the NIMR's redesign, Kellaway put aside his directorial duties for three months in 1936 to plan both the new hospital and his own establishment. ${ }^{131}$ In the event, the Hall Institute remained physically and contractually attached to the hospital at its new site, a pragmatic financial compromise that moreover allowed researchers to retain ward beds. However, the negotiations which had started in 1926 were not finalized until 1944, by which time Burnet had succeeded to the directorship: Kellaway never became professor of experimental medicine. ${ }^{132}$ Nevertheless, on the eve of the Second World War, he was compensated by having established the first functioning medical research unit in Australia.

\section{Solvency and Science}

Narratives of the early Australian institutes bemoan equally a stultifying bondage to clinical medicine and an enduring quest for financial independence. This is frequently a teleological tale in which scientific toil and talent are finally rewarded in 1937 by a deus ex machina, viz. the National Health and Medical Research Council. ${ }^{133}$ Yet as international circumstances illustrate, neither federal support for medical research in Australia, nor the form it finally took, were inevitable. Rather, these structures were contingent both upon the prevailing clinical focus of local medicine and numerous financial experiments undertaken by Kellaway and his compatriots. Thus while the structure of interwar Australian institutes reflected European exemplars, their funding arrangements more closely resembled North American models. British support for national medical science, for instance, was formalized via the MRC in 1913, yet predated by the Indian Research Fund Association, which fostered colonial medical scientists and their institutes from 1911. ${ }^{134}$ In Canada, by contrast, the National Research Council only sporadically funded medical science prior to the Second World War, while in the USA the National

\footnotetext{
${ }^{129}$ UMA, ASAP 3/3/85, Folder 8/5, 'Report of the organisers to the Committee of Management of the Royal Melbourne Hospital', 2 Apr. 1936, p. 28.

${ }^{130}$ UMA, op. cit., note 33 above, p. 3.

131 Tansey, op. cit., note 78 above, p. 1342; UMA, ASAP 3/3/85, Folder 8/2, 'Extract from minutes of meeting of committee of management', 4 Feb. 36, p. 1.

${ }^{132}$ In fact, Australia's first professor of experimental medicine was appointed in 1938 at the
}

\footnotetext{
University of Adelaide, namely Edward Hurst, director of the IMVS from 1936-43.

${ }^{133}$ For example, Moyal, op. cit., note 6 above, pp. 305-7; Roe, op. cit., note 38 above, pp. 76-7.

${ }^{134}$ For the British funding environment prior to 1913, see E M Tansey, 'The funding of medical research before the Medical Research Council.', J. R. Soc. Med., 1994, 87: 546-8; thereafter, see Austoker, op. cit., note 79 above; Kohler, op. cit., note 77 above. For India, see Arnold, op. cit., note 1 above.
} 


\section{Peter Graeme Hobbins}

Institute of Health (1930) represented the first major federal support for biomedical research. $^{135}$

Unsurprisingly, both Australian and American institutional histories spanning the Depression emphasize not only the need for sound financial management, but reveal that research programmes - and their rhetoric-were frequently tailored to accommodate potential sources of income. ${ }^{136}$ Where they differed, however, was in the scale of nongovernment funding. Whereas the millions offered by the Rockefeller Foundation, Carnegie Corporation and Nuffield Foundation called the tune for numerous northern universities and institutes, in Australia the sums proffered were several orders of magnitude lower. For instance, the estate of Thomas Baker, Alice Baker and Eleanor Shaw bestowed $£ 3000$ for facilities in 1926, the trustees of Fusajiro Kanematsu $£ 25,000$ in 1929 , and Eva Kolling $£ 5000$ in 1930 , while annual stipends included $£ 2500$ provided by the Walter and Eliza Hall Trust in 1915 and $£ 3500$ by the Baker endowment a decade later. ${ }^{137}$ Many of these institutes' allowances were supplemented by the associated hospital or state government, but even by 1937 annual incomes rarely exceeded $£ 10,000$. Moreover, much of this funding was contingent upon investment returns and partisan political support. None of the institutes could be described as subsisting on a stable financial base, nor could they anticipate the industry royalties that increasingly accrued to products of basic research in Canada and the USA. ${ }^{138}$ Indeed, this penury was a key factor in the continuing appeal of clinical postings over a local career in research. Weary of official antagonism and the uncertain future of the AITM, even Anton Breinl-the first director of the first Australian institute-resigned in 1920 to pursue "more lucrative private practice" in Townsville. ${ }^{139}$

Arriving in 1923 from the well-resourced British laboratories, Kellaway was doubtless shocked by the parsimony of the Hall Institute's income. Even in 1927, Burnet remarked from the Lister Institute that "The bill for animals and their maintenance here is over $£ 3000$ a year. The W. \& E. H [sic] has an income of about that extent to pay its staff and run the whole show". ${ }^{140}$ Kellaway successfully campaigned for an increase in the Institute's annual stipend, but the more profound change was wrought in 1924 when he obtained permission to seek funding outside the annual grant. ${ }^{141}$ His courting of the Melbourne establishment soon paid off, as his personal charm and growing coterie attracted potential donors such as the medical industrialists George Nicholas and Russell

\footnotetext{
${ }^{135} \mathrm{Li}$, op. cit., note 59 above, p. 192; Victoria A Harden, Inventing the NIH: federal biomedical research policy, 1897-1937, Baltimore, Johns

Hopkins University Press, 1986, pp. 161-5; Daniel $\mathrm{J}$ Kevles, 'Foundations, universities, and trends in support for the physical and biological sciences, 1900-1992', Daedalus, 1992, 121: 195-235, pp. 197-208.

${ }^{136}$ This process was, of course, also observed in Britain: see Jones and Rahman, op. cit., note 123 above.

${ }^{137}$ De Vahl Davis, op. cit., note 11 above, p. 32; Lowe, op. cit., note 50 above, p. 36; Anon., 'Medical research. The Kolling Institute. Ceremony performed by Governor', The Sydney Morning Herald (Sydney),
}

28 July 1930: 8; Courtice, op. cit., note 51 above, pp. 118-19. During this period, the Australian pound was valued at between 75 per cent and 93 per cent of pounds sterling.

${ }^{138}$ See especially Alison Li, 'J. B. Collip, A. M. Hanson and the isolation of the parathyroid hormone, or endocrines and enterprise', J. Hist. Med. Allied Sci., 1992, 47: 405-38; Rasmussen, op. cit., note 24 above.

${ }^{139}$ Anderson, op. cit., note 42 above, p. 145.

${ }^{140}$ UMA, ASAP $3 / 3 / 85$, Frank Macfarlane Burnet to Linda Druce, 18 Mar. 1927, p. 1.

${ }^{141}$ De Vahl Davis, op. cit., note 50 above, pp. 37-9. 


\section{The Tenuous Trajectories of Medical Research in Interwar Australia}

Grimwade. ${ }^{142}$ Burnet later railed, "It is not fitting that a first class scientist should have to go cap in hand for small sums wherever he could find them", but in the 1920s Kellaway had few alternatives. ${ }^{143} \mathrm{He}$ saw fundraising as a necessary yet unpleasant duty, opining to one staff member, "The extraction process, Clyde, stinks a bit.", Nevertheless, his efforts almost immediately secured a generous gift of $£ 3000$ to create a library, followed by $£ 1500$ per annum for three years to establish the biochemistry department. Additional donations followed, but these rapidly withered away after 1929.

Although the enormous potential of mass subscriptions had become apparent during the First World War, such approaches to the populace were rarely undertaken by interwar research institutions. Those which did were generally dismal failures. The Lister Institute did not pursue general appeals and the NIMR was securely funded by the state. ${ }^{145}$ While St Mary's Hospital Medical School in London experienced little trouble raising $£ 105,000$ to rebuild its inoculation department in the late 1920s, only $£ 22,000$ was generated externally. ${ }^{146}$ The British Empire Cancer Campaign was constituted in 1923 on the premise of a massive fund-raising scheme intended to secure $£ 2$ million for the Imperial Cancer Research Fund, but receipts for both ventures fell far short of their goals. ${ }^{147}$ Likewise, in 1921, the nascent Gorgas Memorial Institute of Tropical and Preventive Medicine set a target of $\$ 6$ million via appeals to the American public. Despite strenuous fundraising efforts, the final income amounted to little over $\$ 9000$; entreaties to state medical societies brought in exactly $\$ 7$. As Kellaway had found, significant public income only eventuated when one motivated board member beseeched individual benefactors. ${ }^{148}$ The situation had worsened by 1930, when the embryonic National Institute of Health attracted only $\$ 57$ in public subscriptions. Despite a subsequent campaign of letter writing and personal visits to 3000 potential benefactors - even offering to target research to diseases of personal relevance-by 1933 no further funds emerged. ${ }^{149}$

One can thus appreciate why Kellaway pinned few hopes on the public as a potential source of revenue; certainly the Baker, Kanematsu, and Kolling Institutes appear not to have approached the populace for donations. The Hall Institute did, however, experiment with an appeal in 1924 that achieved its limited objective of raising nearly $£ 3000$, but this tactic was never repeated. ${ }^{150}$ This is surprising given that the same period witnessed the outstanding results achieved by the Sydney Cancer Research Committee. Hamersley has outlined how this group crafted a highly successful fundraising strategy, enlisting a cadre of business leaders and prominent citizens to raise $£ 100,000 .{ }^{151}$ They instigated a public appeal which after several years had reached the creditable sum of

\footnotetext{
${ }^{142}$ Burnet, op. cit., note 64 above, p. 204; Michael Kellaway to Peter Hobbins (in possession of the author), 1 Mar. 2007, p. 1.

${ }_{143}$ Burnet, op. cit., note 64 above, p. 204.

${ }^{144}$ Scaife, op. cit., note 117 above, p. 4.

${ }^{145}$ Chick, Hume and Macfarlane, op. cit., note 82 above, pp. 123-4.

${ }_{146}$ Ronald Hare, 'The scientific activities of Alexander Fleming, other than the discovery of penicillin', Med. Hist., 1983, 27: 347-72, p. 356 .

${ }^{147}$ Austoker, op. cit., note 1 above, pp. 76-7, 88.
}

\footnotetext{
${ }^{148}$ Willard H Wright, 40 years of tropical medicine research: a history of the Gorgas Memorial Institute of Tropical and Preventive Medicine, Inc. and the Gorgas Memorial Library, Washington, Reeves Press, 1970, pp. 4-11.

${ }^{149}$ Harden, op. cit., note 135 above, pp. 161-5.

${ }^{150} \mathrm{~J} \mathrm{H}$ Macfarland and J Monash, Information regarding the Walter and Eliza Hall Institute of Research in Pathology and Medicine, Melbourne, University of Melbourne, 1924; Kellaway, op. cit., note 84 above, pp. 3, 12 .

${ }^{151}$ Hamersley, op. cit., note 23 above, pp. 201-2.
} 


\section{Peter Graeme Hobbins}

$£ 23,000$ - equivalent to that sourced by St Mary's Hospital in London. When relaunched in July 1926 with a focus on funds being used for cancer treatment as well as research, the appeal reached $£ 130,000$ within a year. Even allowing for the special place cancer had occupied as a charitable cause since the turn of the century, ${ }^{152}$ this was a staggering sum, equivalent to over a decade's annual expenditure for the Hall Institute. The success of the Sydney Committee's work was common knowledge at the time, yet when their appeal closed in July 1927 Kellaway apparently did not contemplate a follow-on campaign. Instead, he turned to another, no less daunting source: the Commonwealth government.

\section{Fostering Federal Funding}

Unlike the UK, where laboratory culture and scientific medicine largely predated - and informed-government responsibility for health, in Australia this circumstance was essentially reversed. Thus formalized research institutes not only had to negotiate with practitioners and academics for a place in the medical hegemony; in a sense they also competed against the federal government in siphoning authority from clinical medicine. Whilst the Commonwealth Department of Health was formed only in 1921 and remained closely under Treasury scrutiny, its Director-General-Cumpston-was nationalist, expansionist and autocratic. In his schema, medical research sat below public health and quarantine measures as a national priority. ${ }^{153}$ Indeed, in the wake of the 1925 Royal Commission on Health, he had overseen the winding down of the federally funded AITM.

Kellaway was well aware of the monies provided to British research institutions by the MRC, and the priority it accorded basic physiological, pathological and biochemical investigations. ${ }^{154}$ Indeed, he was among a number of university deans and institute directors who lobbied alongside the BMA for the formation of an equivalent body in Australia. ${ }^{155}$ Cumpston, however, was opposed to replicating the structure, operation and largesse of the MRC, which he believed "would at the best produce an isolated body weak in numbers and with limited influence-consisting moreover of persons who would be administering funds from which they (professionally) would be the principal beneficiaries". ${ }^{156}$ However, this did not signal that he was unsympathetic to medical research per se. ${ }^{157}$ Decades later, when Kellaway advised that he was leaving Australia to take up the directorship of Scientific Policy for the Wellcome Research Laboratories in London, Cumpston revealed that:

In 1924, in an interview between Sir Henry Welcome [sic] and myself, we arrived at an unwritten gentlemen's agreement that his interests would do nothing to disturb my attempts to establish

\footnotetext{
${ }^{152}$ John V Pickstone, Ways of knowing: a new history of science, technology and medicine, University of Chicago Press, 2001, p. 182.

${ }^{153}$ Spencer, op. cit., note 5 above, pp. 188-9; James A Gillespie, The price of health: Australian governments and medical politics 1910-1960, Cambridge University Press, 1991, p. 52.

${ }^{154}$ See, for example, Austoker, op. cit., note 79 above, p. 26; Cantor, op. cit., note 31 above, p. 202.
}

\footnotetext{
${ }^{155}$ Lowe, op. cit., note 50 above, p. 19; Gillespie, op. cit., note 153 above, p. 51 .

${ }^{156}$ Spencer, op. cit., note 5 above, p. 256.

${ }^{157}$ See also J H L Cumpston, National Library of Australia, Canberra, MS 613, 'A philosophy of research: presidential address to the Royal Society of Australia', 18 Mar. 1936, p. 29.
} 


\section{The Tenuous Trajectories of Medical Research in Interwar Australia}

research in Australia on an Australian basis, and that he would do all he could to help ... [such that] we have been left free ... to develop a rapidly expanding and very vigorous and successful national spirit and practice of research. ${ }^{158}$

Cumpston's request was perhaps pointed. Henry Dale's successor as Director of the Wellcome Physiological Research Laboratories was Richard O'Brien, who held the post from 1914 until 1940. ${ }^{159}$ O'Brien—one of Cumpston's former Melbourne University classmates-was another Australian who been imbued with the "Martin spirit" and later claimed credit for helping inspire the AITM's establishment, yet in 1910 he had chosen instead to join the Lister Institute. ${ }^{160}$ Nevertheless, there was certainly a degree of truth in Cumpston's epistle: the Commonwealth government first experimented with funding independent medical research just prior to the 1925 Royal Commission. This commenced, "after a good deal of negotiation", with a grant of $£ 750$ to assist cancer research conducted by Thomas Cherry, the John Grice Cancer Research Fellow whose studies were endorsed by Kellaway and accommodated at the Hall Institute. ${ }^{161}$ The Royal Commission also resulted in the formation of a Federal Health Council, which resolved at its first meeting in January 1927 that "cancer research work should be subsidized as far as practicable" and — buoyed by a substantial budget surplus-began disbursing funds for selected cancer projects the following year. ${ }^{162}$

Thus when Kellaway first approached the Minister of Health for a Commonwealth research grant in November 1927, he was not peremptorily turned away. Cumpston, however, remained the gatekeeper to Kellaway's persistent and adroit entreaties; as chief advisor to successive health ministers, his relationship to Australian medical research echoed that of Walter Morley Fletcher at Britain's MRC. ${ }^{163}$ Cumpston was aware of Kellaway's slow but steady progress in building the profile and finances of the Hall Institute; furthermore, the networks Kellaway had established-and the standing of his institute's scientific work-provided a strong basis for negotiation. Acting on Cumpston's recommendation, the Minister immediately responded to Kellaway's proposal and awarded $£ 2500$ for work in the areas of snake venoms, hydatid disease, cancer diagnosis and infantile paralysis (polio). ${ }^{164}$

This pioneering bestowal of federal subsidies was by no means assured. Cumpston had turned down several entreaties by his own Commonwealth Serum Laboratories for research funds, and his stranglehold on health finances certainly worked against Kellaway's opposite number at the Baker Institute, William Penfold. Indeed-like Breinl before him at the AITM-Penfold had resigned as director of CSL in 1927 after falling foul of Cumpston. ${ }^{165}$ By early 1928, as director at the Baker, he had spearheaded a quite

\footnotetext{
${ }^{158}$ NAA, Series A1928/1, Control 690/2/8/1, J H L Cumpston to C H Kellaway, 7 July 1943.

${ }^{159}$ Douglas, op. cit., note 37 above (part 1), p. 714.

${ }^{160}$ Anderson, op. cit., note 42 above, p. 101.

${ }^{161}$ Syme, op. cit., note 29 above, pp. 226-7, 230.

${ }^{162}$ Anon., Report of the Federal Health Council of Australia. First session held at Melbourne, 25-28th January, 1927, Melbourne, H J Green, 1927, p. 8.
}

\footnotetext{
${ }^{163}$ Kohler, op. cit., note 77 above, pp. 333-4, 343-9.

${ }^{164}$ NAA, Series A1928/1, Control 690/20 Section 1, Charles H Kellaway to the Minister of Health, 21 Nov. 1927 and J H Cumpston to the Minister, 22 Nov. 1927 (including annotations).

${ }^{165}$ Brogan, op. cit., note 14 above, p. 23; Douglas, op. cit., note 37 above (part 2), pp. 786-8.
} 


\section{Peter Graeme Hobbins}

public submission for the federal government to establish a "Medical Research Council to consist of research men, with parliamentary representation ... [and] to keep the Council away from the Public Service control". ${ }^{166}$ Given such impolitic rhetoric, it is unsurprising that the Baker received no government funding throughout Penfold's tenure as director. This situation also occasioned inter-institutional jealousies: in 1932, with the Baker facing closure on account of financial stringencies, its chairman of trustees publicly wrote:

The policy of the Federal Government in the matter of research is well known; the late Government came to the assistance of a sister research unit, the Walter and Eliza Hall Institute associated with the Melbourne Hospital, to the extent of several thousands of pounds. It was on the eve of making a similar grant to us when the great depression arrived, and asked us to waive our claim for the time being. Surely the present Government will not fail us in this crisis. ${ }^{167}$

Despite this rather disingenuous rendering of the Hall Institute subsidy, neither state nor Commonwealth funds were forthcoming.

Conversely, the positive press attention garnered by the Hall Institute precedent reinforced the political value of the small sums allocated ( $£ 10,200$ over four years). Kellaway's position was further strengthened by the sterling service he provided the Commonwealth as chair of a Royal Commission into the 1928 "Bundaberg tragedy", in which twelve children died after receiving contaminated diphtheria toxin-antitoxin manufactured by CSL. ${ }^{168}$ Claire Hooker and Alison Bashford have detailed the centrality of diphtheria prevention to the Commonwealth's expanding immunization strategy, suggesting how vital it was for the investigation-which included considerable work at the Hall Institute-comprehensively to address this public health disaster. ${ }^{169}$ As a result of its painstaking scientific studies, Kellaway's Commission vindicated the Commonwealth's flagship programme while projecting the pragmatic value of medical research to a sceptical nation. ${ }^{170}$

Nevertheless, federal budget cuts curtailed the Commonwealth's fiscal experiment in 1931. By 1934, with the Hall Institute's funds at a nadir, ${ }^{171}$ Kellaway initiated a new tactic by inviting the Commonwealth to join the Rockefeller Foundation in supporting the establishment of a virus research department at his institute. Christopher Sexton asserts that Burnet instigated this proposal, but he considerably understates Kellaway's contribution both as a negotiator and as head of a recognized centre of excellence. ${ }^{172}$ Indeed, while Burnet's personal reputation certainly contributed, without an appropriate infrastructure and depth of research across an institute, Rockefeller funding was far from

\footnotetext{
${ }^{166}$ Lowe, op. cit., note 50 above, p. 19.

${ }^{167}$ J F MacKeddie, 'The Baker Research Institute', The Argus (Melbourne), 7 July 1932: 6.

${ }^{168}$ See C H Kellaway, P MacCallum and A H Tebbutt, Report of the Royal Commission of Inquiry into fatalities at Bundaberg, Canberra, H J Green, 1928; Harry F Akers and Suzette A T Porter, 'Bundaberg's Gethsemane: the tragedy of the inoculated children', R. Hist. Soc. Queensland J., 2008, 20: 261-78.

${ }^{169}$ Hooker and Bashford, op. cit., note 14 above, p. 64; Claire Hooker, 'Diphtheria, immunisation and
} 


\section{The Tenuous Trajectories of Medical Research in Interwar Australia}

assured however talented its individual scientists might be. ${ }^{173}$ Kellaway was not only aware that Foundation funds had been instrumental to Cumpston's "intelligent opportunism" in creating a Commonwealth Department of Health; ${ }^{174}$ he was also personally known to the Rockefeller administrators via his Bundaberg inquiry and had himself received a Foundation fellowship to visit the USA in $1933 .{ }^{175}$ His entrenched relationship with the Australian health bureaucracy, coupled with the Hall Institute's record as a stable and productive research institution, facilitated the success of the virus laboratory scheme. Yet once again - as was the case with federal funding-Morgan was given short shrift when the Baker Institute sought Rockefeller Foundation support. ${ }^{176}$

Commonwealth interest in the virus research programme was also piqued by Kellaway's astute proposal that it should comprise a joint venture with CSL which might lead to marketable vaccines. ${ }^{177}$ The initiative thus formed a relatively rare interwar example of research-industry cooperation in Australia, at a time when such relationships were becoming entrenched in America. ${ }^{178}$ It was not the first: CSL had collaborated with the Hall Institute previously to produce antivenenes and with the Victorian Department for Public Health to develop a polio vaccine. ${ }^{179}$ However, whilst the virus programme represented CSL's entrée into basic research, as a Commonwealth enterprise it was something of a special case. Despite his relationship with local pharmaceutical entrepreneurs such as George Nicholas, Kellaway seems never to have sought more formal industry ties to commercialize the Hall Institute's findings. While "Henry Dale in the UK and A. N. Richards in the USA were 'everywhere' in pharmaceuticals", ${ }^{180}$ Kellaway fostered industry relationships only for benefaction, not for collaboration. Thus while this makes his subsequent appointment to an ostensibly commercial venture-the Wellcome Research Institution-somewhat surprising, by the late 1930s there was clearly no doubt as to Kellaway's impressive skills as a science administrator and negotiator.

\section{Deus ex Machina?}

The virus research programme furthermore confirmed Kellaway's appreciation of the scientific and political capital to be made from the imprimatur of the Rockefeller Foundation. Internationally, it garnered substantial scientific kudos for Kellaway, Burnet and the Hall Institute, while within Australia it confirmed-at federal cabinet level-the potential worth of medical research at a time when parliament was considering the creation of a National Health and Medical Research Council. Indeed, the 1934 virus grant

\footnotetext{
${ }^{173}$ See especially Edgar Jones, 'Aubrey Lewis, Edward Mapother and the Maudsley', in Katherine Angel, Edgar Jones and Michael Neve (eds), European psychiatry on the eve of war: Aubrey Lewis, the Maudsley Hospital, and the Rockefeller Foundation in the 1930s, London, The Wellcome Trust Centre for the History of Medicine at UCL, 2003, pp. 3-38, on pp. 17-18; Katherine Angel, 'Defining psychiatry: Aubrey Lewis's 1938 report and the Rockefeller Foundation', in ibid., pp. 39-56, on pp. 39-40; Li, op. cit., note 59 above, pp. 200-20.

${ }^{174}$ James Gillespie, 'The Rockefeller Foundation, the hookworm campaign and a national health policy
}

in Australia, 1911-1930', in MacLeod and Denoon (eds), op. cit., note 12 above, pp. 64-87, on p. 72. ${ }^{175}$ See, for instance, NAA, Series A1928/1, Control 90/28/3, WA Sawyer to J H L Cumpston, 24 Aug. 1928; WEHA, WEHA00047, Alan Gregg to Charles Kellaway, 15 Nov. 1933.

${ }^{176}$ Lowe, op. cit., note 50 above, p. 37.

${ }^{177}$ NAA, Series A1928/1, Control 690/20 Section 1,

J H L Cumpston to the Minister, 29 Mar. 1934.

${ }^{178}$ MacLeod, op. cit., note 15 above, p. 64;

Rasmussen, op. cit., note 24 above, pp. 178-80

${ }^{179}$ Brogan, op. cit., note 14 above, p. 22.

${ }^{180}$ Pickstone, op. cit., note 152 above, p. 181. 


\section{Peter Graeme Hobbins}

was renewed in 1936 and became one of the few arrangements transferred to the new funding system in $1937 .^{181}$

The historian Michael Roe has commented of the NH\&MRC that "for the first time in Australian history the value of medical research was recognized as an asset in the national economy". ${ }^{182}$ In a general sense this is true, but Kellaway's pioneering requests for federal grants in the preceding decade had been very much couched-and approved - in the rhetoric of national interest. It has also been noted that-in contrast to Cumpston's concerns about an MRC-styled self-serving body-there were in fact no representatives of medical research institutions sitting on the NH\&MRC at its formation. ${ }^{183}$ Ostensibly this is correct, but Kellaway had spent a decade amicably interacting with the Council's foundation chairman, the omnipresent Cumpston. Furthermore, one of the three members of the Council's Medical Research Advisory Committee was Harold Dew, a senior surgeon who had spent five years at the Hall Institute and was favourably disposed towards Kellaway. ${ }^{184}$ As a foundation member of the Association of Physicians of Australasia, which was also represented, Kellaway's assiduous networking once more bore fruit. Indeed, the Hall Institute became, and for many years remained, the single largest beneficiary of NH\&MRC funds, although Kellaway shared a concern with fellow investigators that increasing state control might jeopardize the autonomy of research. ${ }^{185}$

Nevertheless, the Council itself had to fight for its initial endowment and, in financing only specific programmes, its outlays never guaranteed the running expenses of local institutes. ${ }^{186}$ In fact, the Depression had thrown the tenuous finances of Australian medical research into stark relief: by 1932, even the government's scattered Commonwealth Health Laboratories were in jeopardy. ${ }^{187}$ Likewise, despite sporadic attempts to increase the Baker Institute's funding base, it survived only through severe retrenchments and shoring up by the Alfred Hospital and two key benefactors. ${ }^{188}$ A starker contrast is provided by the Sydney Cancer Research Committee, whose funds had totalled $£ 130,000$ in 1927 and whose staff numbers had rivalled those of the Hall Institute before the stock market crash. ${ }^{189}$ Its administrators, however, were profligate to the point of recklessness, leading to the operation being wound up in 1938. Indeed, the director of research, Henry Chapman, committed suicide in 1934 when accused of misappropriating nearly $£ 20,000$ from other programmes. ${ }^{190}$

Kellaway, too, had a difficult time. Vivianne de Vahl Davis believes that the Hall Institute faced closure in the depths of the Depression, as annual income dwindled from $£ 10,509$ in $1928-9$ to $£ 5525$ in $1934-5$. She agreed with Burnet that "any other

\footnotetext{
${ }^{181} \mathrm{C} \mathrm{H}$ Kellaway, The Walter and Eliza Hall Institute of Research in Pathology and Medicine. Summary of the director's nineteenth annual report 1937-38, Melbourne, The Walter and Eliza Hall Institute, 1938, p. 9.

${ }^{182}$ Roe, op. cit., note 38 above, p. 76.

${ }^{183}$ Keogh, op. cit., note 92 above, p. 26.

${ }^{184}$ See, for instance, Harold R Dew, Hydatid disease: its pathology, diagnosis and treatment, Sydney, Australasian Medical Publishing, 1928, p. 5.

${ }^{185}$ De Vahl Davis, op. cit., note 50 above, p. 59; Kellaway, op. cit., note 95 above, p. 374; Keogh, op. cit., note 92 above, p. 26.
}

\footnotetext{
${ }^{186}$ NAA, Series A461/8, Control F347/1/2 part 1, 'Notes of a deputation representative of the National Health and Medical Research Council, which waited upon the Acting Prime Minister', 3 June 1937,

pp. 1-4; Kellaway, op. cit., note 105 above, p. 7.

${ }^{187}$ Whyte, op. cit., note 41 above, p. 31.

${ }^{188}$ Lowe, op. cit., note 50 above, pp. 37-8; Anon.,

'Baker Institute. Severe retrenchment', The Sydney

Morning Herald (Sydney), 14 Feb. 1933: 6.

${ }^{189}$ Hamersley, op. cit., note 23 above, p. 206.

${ }^{190}$ Ibid., pp. 212, 215.
} 


\section{The Tenuous Trajectories of Medical Research in Interwar Australia}

man ... would have given up the struggle and returned to work in England where he had both an excellent scientific reputation and influential friends". ${ }^{191}$ However, Kellaway excelled in economizing and while his administrative record was not without fault, his personal integrity and skills both as a fundraiser and financial manager were critical to the success of his fragile operation throughout the 1930s. Moreover, in securing the Hall Institute's pioneering federal grants, his experiments had contributed to the groundwork for the NH\&MRC. While this helped free succeeding directors from repeating his "cap in hand" forays, it was no panacea; by 1943 Kellaway was repeating a refrain familiar the world over: "All [of the Australian] Institutions need support, none of them being provided with an endowment sufficient for its needs." 192

\section{Conclusions: \\ Cultural Accommodations and Local Exemplars}

One can readily argue that any institution adapting to its historical environment constitutes a ceaseless "experiment" in projecting corporate needs and accommodating local contingencies. What set apart the Australian medical research institutes of the early twentieth century, however, was their proponents' studious attempts to graft models that had evolved outside the local culture onto parochial medical structures. James Gillespie, for instance, argues that an analogous process was undertaken by the International Health Board of the Rockefeller Foundation, whose 1919-24 hookworm campaign unsuccessfully sought to formalize Australian health bureaucracies along rigidly American lines. ${ }^{193}$ Rather than dogmatically persisting with received prototypes, however, the early research institutes reconfigured themselves time and again to thrive in this unpromising soil. It was only via such protean measures that a handful of endeavours were able to embed themselves in the local medical culture, negotiating a limited degree of independence and continuity for the pursuit of basic science. In this regard, the Hall Institute was undoubtedly the most successful of the pre-1939 ventures, as the structures set up by Kellaway came increasingly to dominate Australian conceptions of a medical research institute. ${ }^{194}$

But this was merely an evolutionary formula for survival, not prosperity. Even after the formation of the NH\&MRC, the early institutes could conceivably have remained clinical appendages subsisting on short-term, pragmatic investigations. Indeed, this was the path taken by most centres after the outbreak of war in 1939. Despite a vast increase in federal support, routine duties such as blood grouping of service personnel proliferated, while research agendas were tightly directed toward the pressing needs of national efficiency and defence. ${ }^{195}$ The concordance of research institutes with this national

${ }^{191}$ De Vahl Davis, op. cit., note 50 above, pp. 46-8; F M Burnet, UMA, ASAP 3/3/85, Folder 6/21, 'Charles Halliley Kellaway MD MS FRS (handwritten draft for Med. J. Aust.)', 1953, p. 3.

${ }^{192}$ Kellaway, op. cit., note 105 above, p. 7.

193 Gillespie, op. cit., note 174 above.

${ }^{194}$ For instance, see Courtice, op. cit., note 51 above, pp. 119-21; Frank Fenner and David Curtis, The John Curtin School of Medical Research: the first fifty years, 1948-1998, Gundaroo, Brolga Press, 2001, pp. 1-11.

${ }^{195}$ Although the effect of the Second World War on Australian medical research is beyond the scope of this article, see especially Allan Walker's fourvolume official medical history of the war, op. cit., note 127 above; R W Home, 'Science on service, 1939-1945', in Home (ed.), op. cit., note 21 above, pp. 220-51; Michelle Freeman, 'Australian 


\section{Peter Graeme Hobbins}

mobilization was understandable, but betrayed the still-fragile foundations underlying basic science and exacerbated their financial dependence on the Commonwealth.

Nevertheless, by the late 1930s — and certainly after 1945-it was clear that a cultural shift had occurred in Australian attitudes towards medical research. Swelling university enrolments and the instigation of a fourth medical faculty at the University of Queensland (1936) certainly contributed, as did an influx of philanthropic support for integrating research into teaching. ${ }^{196}$ The idea-if not the initial reality-of the NH\&MRC also embodied a new national commitment to original investigations, and was lauded by clinicians and scientists alike. The astounding clinical success of penicillin and Howard Florey's 1945 Nobel Prize clearly inspired his compatriots, although he himself was never quite persuaded to work in Australia. ${ }^{197}$ Thus although the post-war environment remained far from ideal, and senior investigators including Kellaway continued to depart for more conducive overseas facilities through the $1940 \mathrm{~s},{ }^{198}$ medical science was increasingly seen as a rewarding career that Australians could—and should—pursue in their homeland.

Above all, it was the seminal research institutes that had consistently provided the exemplars, facilities and infrastructure to foster this new perception. This was certainly the case for the Hall Institute, which in 1948 Florey opined had "brought more renown to Australian research than any other Institute". ${ }^{199}$ Beyond ensuring the bare survival of his laboratory Kellaway had projected a culture of experiment outwards, titrating incremental changes in hospital practice, clinical teaching, health policy, fiscal support and public benefaction. His institute remained more than an isolated centre for basic science; it became a site of national interest, even pride. In negotiating a wider cultural role for medical research far from London, Paris or Berlin, Charles Kellaway's experiments paralleled those of James "Bert" Collip in Canada or Argentina's Bernardo Houssay. ${ }^{200}$ In this sense he had remained, indeed, a "medical missionary".

universities at war: the mobilisation of universities in the battle for the Pacific', in Roy MacLeod (ed.), Science and the Pacific war: science and survival in the Pacific, 1939-1945, Dordrecht, Kluwer

Academic, 2000, pp. 119-38; Mark W Cortiula, 'Serum and the Soluvac: the Australian approach to whole blood substitutes and blood transfusion during the Second World War', J. Hist. Med. Allied Sci., 1999, 54: 413-38; Tom Sweeney, Malaria frontline: Australian Army research during World War II, Carlton, Melbourne University Press, 2003; Bridget Goodwin, Keen as mustard: Britain's horrific chemical warfare experiments in Australia, St Lucia, University of Queensland Press, 1998.

${ }^{196}$ Whyte, op. cit., note 41 above, pp. $42-58$; McPhee, op. cit., note 28 above, pp. 47-52.

\footnotetext{
${ }^{197}$ Milton Lewis, 'The idea of a national university: the origins and establishment of the Australian National University', ANZHES J., 1979, 8: 40-55.

${ }^{198}$ Douglas R Wright, 'Why we lose our best scientists', (unknown newspaper) (Melbourne) c.1946.

${ }^{199}$ Australian National University, op. cit., note 35 above, p. 10.

${ }^{200}$ Virgilio G Foglia, 'The history of Bernardo A Houssay's research laboratory, Instituto de Biología y Medicina Experimental: the first twenty years, 1944-1963', J. Hist. Med. Allied Sci., 1980, 35 : 380-96; Li, op. cit., note 59 above, pp. 245-8.
} 